\title{
Cutaneous primary B-cell lymphomas: from diagnosis to treatment ${ }^{*}$
}

\author{
Margarida Lima ${ }^{1}$
}

DOI: http:/ /dx.doi.org/10.1590/abd1806-4841.20153638

\begin{abstract}
Primary cutaneous B-cell lymphomas are a heterogeneous group of mature B-cells neoplasms with tropism for the skin, whose biology and clinical course differ significantly from the equivalent nodal lymphomas. The most indolent forms comprise the primary cutaneous marginal zone and follicle center B-cell lymphomas that despite the excellent prognosis have cutaneous recurrences very commonly. The most aggressive forms include the primary cutaneous large B-cell lymphomas, consisting in two major groups: the leg type, with poor prognosis, and others, the latter representing a heterogeneous group of lymphomas from which specific entities are supposed to be individualized over time, such as intravascular large B-cell lymphomas. Treatment may include surgical excision, radiotherapy, antibiotics, corticosteroids, interferon, monoclonal antibodies and chemotherapy, depending on the type of lymphoma and on the type and location of the skin lesions. In subtypes with good prognosis is contraindicated overtreatment and in those associated with a worse prognosis the recommended therapy relies on CHOP-like regimens associated with rituximab, assisted or not with local radiotherapy. We review the primary cutaneous B-cell lymphomas, remembering the diagnostic criteria, differential diagnosis, classification, and prognostic factors and presenting the available therapies.

Keywords: Antineoplastic combined chemotherapy protocols; Follicular lymphoma; Interferon-alpha; Lymphoma, B-Cell; Lymphoma, B-Cell, marginal zone; Lymphoma, large B-cell; Monoclonal antibodies; Radiotherapy; Pseudolymphoma; Skin neoplasms
\end{abstract}

\section{INTRODUCTION}

Primary cutaneous lymphomas (PCL) are the most frequent extra-nodal lymphomas, with incidence around 10 cases per million inhabitants per year, from which $20-30 \%$ are primary cutaneous B-cell lymphomas (PCBCL). ${ }^{1,2}$ Although its physiopathology is still poorly understood, the origin appears to be multifactorial and its genesis probably involves chronic antigen stimulation, such as that associated with bacterial and viral infections. Skin lesions consist of patches, plaques, nodules or tumors, and may be single or multiple. Given the clinical suspicion, the diagnosis is established by skin biopsy, through histological and cytological examinations, eventually complemented by immunohistochemical and immunophenotypic, cytogenetic and genotypic studies. ${ }^{3-8}$ The differential diagnosis includes mainly pseudolymphomas and primary cutaneous T-cell lymphomas (PCTCL), as well systemic B-cell lymphomas with cutaneous involvement. ${ }^{3-8}$

Like other cutaneous lymphomas, PCBCL are categorized according to the classification of the consensus between World Health Organization (WHO) and European Organization for Research and Treatment of Cancer (EORTC), from 2005, and the WHO classification of cancers of the hematopoietic and lymphoid tissues, last updated in 2008. ${ }^{9-11}$ The WHO-EORTC schema includes three major categories of PCBCL, which differ from the biological point of view and cor-

Received on 20.04.2014

Approved by the Advisory Board and accepted for publication on 05.06.2014

Study performed at Serviço de Hematologia Clínica. Hospital de Santo António (HSA), Centro Hospitalar do Porto (CHP) - Porto, Portugal.

Financial Support: None.

Conflict of Interest: None.

1 Hospital de Santo António, Centro Hospitalar do Porto - Porto, Portugal.

C2015 by Anais Brasileiros de Dermatologia 
respond to different clinical and laboratory features: a) primary cutaneous marginal zone lymphoma (PCMZL), originating from the mucosa-associated lymphoid tissue (MALT), more specifically from the skin associated lymphoid tissue (SALT); b) primary cutaneous follicle center lymphoma (PCFCL), originating from cutaneous follicle center B-cells; and c) primary cutaneous large B-cell lymphoma (PCLBCL), in which two major groups are individualized, "leg type" and "others", the latter being heterogeneous (Chart 1). ${ }^{10}$

The clinical course of PCBCL is generally more indolent and the prognosis is usually more favorable than that of their nodal counterparts, despite the high rate of cutaneous recurrences. ${ }^{3-8}$ PCMZL and PCFCL types have an excellent prognosis, with 5 year survival rates higher than $90 \%$ in both cases, while for PCLB$\mathrm{CL}$, particularly leg type, prognosis is more reserved, with 5-years survival rate lower than $60 \%$. $3-8$

The available therapeutic modalities are diverse and include surgical excision, radiotherapy, corticosteroids, antibiotics, monoclonal antibodies and interferon, as well as monotherapy or polychemotherapy schemas. Treatment should be tailored according to the risk and selected based on the type of lymphoma and on the clinical stage, as well as on the characteristics of the patient and the number, type, extent, location and distribution of the skin lesions. ${ }^{3-8}$

We review PCBCL, remembering their classification, diagnostic criteria, differential diagnosis and prognostic factors, and presenting the available therapies.

\section{EPIDEMIOLOGY}

An American epidemiological study published in 2009, based on analysis of 3,884 cases of PCL diagnosed in the United States between 2001 and 2005, revealed that $71 \%$ were PCTCL (7.7 cases/ million inhabitants/ year) and 29\% were PCBCL (3.1 cases/ million

Chart 1: Classification of the primary cutaneous B-cell lymphomas, as proposed by WHO and EORTC

1. Primary cutaneous marginal zone lymphomas

2. Primary cutaneous follicle center cell lymphomas

3. Primary cutaneous large B-cell lymphomas

3.1. Primary cutaneous large B-cell lymphomas, leg type

3.2. Primary cutaneous large B-cell lymphomas, other

3.2.1. Intravascular large B-cell lymphomas

3.2.2. Other primary cutaneous large B-cell lymphomas

Source: Willemze R et al, $2005^{10}$

Abbreviations: WHO, World Health Organization; EORTC, European Organization for Research and Treatment of Cancer inhabitants/ year). ${ }^{2}$ In addition, it showed that the incidence of PCL is higher in men than in women (14.0 versus 8.2 cases/ million inhabitants/ year, with a male/ female ratio of 1.72). Also, it's higher in blacks, intermediate in Hispanic Caucasians and lower in Asians (11.5, 7.9 and 7.1 cases/ million inhabitants/ year, respectively). The highest incidence of PCTCL was observed in blacks, while the highest incidence of PCBCL was observed in non-Hispanic Caucasians (10.0 and 3.5 cases/ million inhabitants/ year, respectively). This study also showed an increased incidence of PCL in the years 2001-2003, compared to that observed in the years 1980-1982 (14.3 and 5.0 cases/ million inhabitants/ year, respectively), stabilizing between 2004 and 2005 (12.7 cases/ million inhabitants/ year). ${ }^{2}$

\section{PHYSIOPATHOLOGY}

The physiopathology of PCBCL is only partially understood. It is believed that they begin as reactive inflammatory lymphoproliferative processes and that lymphomagenesis occurs in successive steps. Hence there are "borderline cases" in which it is difficult to distinguish between pseudolymphomas (reactive lymphoid hyperplasias) and real lymphomas. The transition from a pre-neoplastic to a neoplastic condition seems to be determined by imbalance between cell proliferation and apoptosis, deregulation of major biochemical pathways for intracellular signal transmission, cell adhesion and migration, as well as expression of oncogenes and/or inhibition of tumor suppressor genes.

Chronic antigenic stimulation and viral and bacterial infections appear to be predisposing factors, but studies to support these assumptions are scarce and, in most cases, the etiologic agent is not known. ${ }^{12-17}$ Regarding viral infections, an important role of the herpes viruses, such as Epstein Barr virus (EBV) and Human Herpes Virus type 8 (HHV8), was noted in the genesis of some lymphomas, particularly in those occurring in immunocompromised individuals, such as in patients infected with human immunodeficiency virus (HIV) and in transplant recipients. ${ }^{12}$ Also noteworthy is the possible association between Hepatitis C Virus (HCV) infection and PCBCL. ${ }^{13,14}$ Concerning bacteria, PCMZL have been associated with Borrelia burgdorferi infection, although the subject is still controversy. ${ }^{15-21}$

Cutaneous B-cell lymphomas have also been described in patients treated with methotrexate, in particular for rheumatoid arthritis. ${ }^{22}$ In many of these cases, EBV has been documented in B-cells lymphoma and regression of lesions has occurred after discontinuation of the drug, suggesting that methotrexate induced immunosuppression have had a decisive role in triggering the lymphoproliferation. ${ }^{22-25}$ 


\section{DIAGNOSIS}

\section{Clinical manifestations}

PCBCL manifest by patches, plaques and non-ulcerated nodules and/or tumors, single or multiple, usually with firm consistency. Although extracutaneous dissemination may occur, in most cases the disease remains localized to the skin. $\cdot^{3-8}$ Given the clinical suspicion, the diagnosis is established by performing a biopsy of the skin lesions, through histological and cytological examinations, complemented by phenotypic and genotypic studies. ${ }^{3-8}$

\section{Histology and cytology}

The pattern of cutaneous involvement by PCBCL differs from that observed in PCTCL, being characterized by a nodular or diffuse, often sharply demarcated, non-epidermotropic lymphoid infiltrate, located predominantly in the dermis, and sparing the sub-epidermal "Grenz zone".${ }^{26}$ From a cytological viewpoint, neoplastic B-cells resemble normal B-cells that give rise to them, i.e. centrocytes and centroblasts in the case of PCFCL, monocytoid marginal zone B-cells and plasma cells in the case of PCMZL, and centroblasts, immunoblasts or anaplastic cells in the case of PCLBCL.

\section{typing}

Immunohistochemistry and immunopheno-

Immunohistochemistry for lymphoma characterization should include different types of markers: a) markers to demonstrate B-cell origin (e.g. CD19, CD20 and CD79a); b) markers to characterize expanded B-cell population (e.g., CD5 and CD10) and to evaluate clonality (immunoglobulin kappa and lambda light chains); as well as c) markers to characterize accompanying cells consisting of plasma cells (e.g. CD138), T-cells (e.g. CD3, CD4, CD8), and follicle dendritic cells (e.g. CD21).

In general, B-cells stain positively for CD19, CD20, CD79, mu (IgM) or gamma (IgG) immunoglobulin (Ig) heavy chains, and kappa or lambda Ig light chains, and they are negative for T-cell markers (i.e., $\mathrm{CD} 2, \mathrm{CD} 3, \mathrm{CD} 4, \mathrm{CD} 7$ and CD8). In addition, CD5 is useful to exclude secondary skin involvement by chronic lymphocytic leukemia/ small lymphocytic lymphoma (CLL/SLL) and mantle cell lymphoma (MCL), whereas CD10 may be positive in follicle center lymphoma, particularly in those from nodal origin. ${ }^{27}$

One question that often arises is the differential diagnosis between PCLBCL-leg type and other PCL$\mathrm{BCL}$, particularly PCFCL with diffuse growth pattern and predominance of centroblasts. In this regard, it is useful to assess the expression of other molecules in the neoplastic B-cells, such as MUM1/IRF4 (Multiple Myeloma 1 / Interferon Regulatory Factor 4), BCL2
(B-Cell Lymphoma 2), BCL6 (B-Cell Lymphoma 6) and HGAL (Human Germinal center-Associated Lymphoma). A study in which these antigens were evaluated by immunohistochemistry showed that the combination of BCL6 with HGAL has high sensitivity and specificity for the diagnosis of PCFCL whereas positivity for BCL2 and MUM1/IRF4 favors the diagnosis of PCLBCL-leg type. ${ }^{28}$ Thus, MUM1, BCL2 and BCL6 molecules are useful for distinguishing PCLBCL-leg type (BCL2+, BCL6-/+, MUM1+) from PCFCL (BCL2/+, BCL6+, MUM1-) and PCMZL (BCL2+, BCL6-, MUM1-).

\section{Genetics and cytogenetics}

The study of molecular rearrangements of genes encoding Ig heavy chains (IGH) is useful to differentiate PCBCL from pseudolymphomas. Until recently, cytogenetic studies had limited value in the diagnosis of PCBCL, since recurrent chromosomal and molecular alterations were unknown. ${ }^{23}$ In particular, most PCFCL do not express $t(14,18)$ ( $q 32, q 21)$ that determines BCL2-JH rearrangement and features nodal FL. Likewise, PCMZL cells do not have, in general, the cytogenetic abnormalities found in nodal MZL. ${ }^{29}$

More recent studies performed by comparative genomic hybridization (CGH), using microarrays and subsequently confirmed by fluorescence in situ hybridization (FISH) enabled to detect a large number of recurring genetic aberrations in PCLBCL-leg type, and, although less frequently, in PCFCL with predominance of large cells; in contrast, they are rarely found in indolent PCFCL and PCMZL.

One of the genes involved recurrently in PCLBCL-leg type is CDKN2A (cyclin-dependent kinase inhibitor 2A) gene, located in the 9p21 region, which often suffers deletion or inactivation in order to promote hypermetilation..$^{30-32}$ This gene encodes for the protein p16 (also known as INK4, inhibitor of kinase 4), an inhibitor of cell proliferation pathway dependent on CDK4 (cyclin-dependent kinase 4) (p26-INK4/CDK4 axis), as well as for the protein p14 (also known as $\mathrm{ARF}$, alternate open reading frame), which acts by stabilizing the p53 protein (p14-ARF/p53 axis). Such genetic aberrations result in instability/degradation of p53 protein. In addition, the increase in CDK4 activity determines the inactivation of $\mathrm{Rb}$ (retinoblastoma) protein, coded by the RB1 gene located in the region 13q14.2, which negatively regulates cell cycle progression (p26-INK4 axis/Rb), resulting in increased cell proliferation. ${ }^{30-32}$ Other changes described as being recurrent in PCLBCL-leg type are DNA amplifications in the region 18q21.31-q21.33, which includes BCL2 and MALT1 genes, as well as $\mathrm{t}(8,14)(\mathrm{q} 24, \mathrm{q} 32) \cdot{ }^{30,31}$

A study in which 31 patients with PCBCL (19 with PCFCL and 12 with DLBCL-leg type) were evalu- 
ated using $\mathrm{CGH}$, revealed that most PCFCL cases have recurrent DNA amplifications at 2p16.1 region, with amplification of c-REL gene (63\% of the cases), and deletions in region $14 q 32.33$ (68\% of the cases). ${ }^{30}$ The same study showed that PCLBCL-leg type cases have recurrent DNA amplifications in region 18q21.31-q21.33 (67\% of the cases), which includes BCL2 and MALT1 genes, and recurrent homozygous DNA deletions in region 9p21.3 (42\% of the cases), which contains CDKN2A, CDKN2B and NSG-x genes. In addition, some patients with PCLBCL-leg type $(17 \%)$ have a complete hypermethylation of CDKN2A gene promoter.

Another study with a smaller number of patients (4 with PCMZL; 7 with PCFCL with small cells; 4 with PCFCL with large cells; 6 with PCLBCL-leg type) confirmed the existence of deletions in 9p21 region, containing CDKN2A gene, which encodes p16 (INK4) and p14 (ARF) proteins, in all PCLBCL-leg type, and deletions in 1p36 region in all PCFCL with large cells. ${ }^{31}$ Furthermore, presence of $t(8 ; 14)(q 24, q 32)$ was demonstrated by FISH in 2 of 6 (33\%) DLBCL-leg type analyzed. ${ }^{31}$

Finally, a study in which changes in genes codifying for p26, p14, p53 and Rb were examined by FISH and immunohistochemistry in 22 patients with PCBCL (9 with PCFCL; 7 with PCMZL; 6 with PDLBCL-leg type) revealed alterations of CDKN2A, TP53 and RB genes in most patients with DLBCL-leg type. These changes are exceptionally rare in PCFCL and PCMZL. ${ }^{32}$

Gene expression studies are useful to distinguish PCBCL subtypes. ${ }^{33,34}$ Primary cutaneous MZL usually have a "plasma cell" pattern of gene expression, while PCFCL usually have overexpression of SPINK2 gene, and a "germinal center B-cell" pattern of gene expression. ${ }^{33,34}$ In contrast, PCLBCL-leg type usually have an increased expression of genes involved in cell proliferation, proto-oncogenes (PIM-1, MIP-2 and c-MYC), as well as of genes encoding transcription factors (IRF4 and OCT-2), corresponding to an "activated B-cell" pattern. ${ }^{34}$

\section{DIFFERENTIAL DIAGNOSIS}

\section{Primary cutaneous T-cell lymphoma}

In general, the cytological and histological aspects observed in PCBCL differ from that observed in PCTCL. ${ }^{23,26}$ Histologically, the pattern of infiltration observed is described as being "ball-shaped" and "non-epidermotropic" in PCBCL, and "horizontal", "disc-shaped" and epidermotropic in PCTCL. In addition, neoplastic T-cells tend to have an indented and cerebriform nucleus, while neoplastic B-cells may have the aspect of centrocytes, centroblasts, immunoblasts or plasmablasts. Regardless the morphological differences, the immunophenotypic characterization of neoplastic cells by immunohistochemistry and/or flow cytometry is critical to distinguish a T-cell lymphoma (e.g. CD2, CD3, CD4 and CD8) from a B-cell lymphoma (e.g. CD19, CD20 and CD79).

\section{Cutaneous pseudolymphoma}

The differential diagnosis between a "pseudolymphoma" (reactive lymphoid hyperplasia) and a PCBCL (follicle center or marginal zone type) can be very difficult. ${ }^{26,35-37}$ Primary cutaneous B-cell lymphomas, like "pseudolymphomas", may sometimes be manifested by skin lesions in insect bite, vaccination or tattoo sites. From the histological point of view, in "pseudolymphomas" it is generally observed a nodular infiltration of the dermis by lymphoid cells, which can form germinal centers, together with macrophages with cytoplasm loaded with debris, with aspect of "starry sky". T-cells, plasma cells and eosinophils are usually more abundant at the periphery of the nodules and in the interfollicular regions. The demonstration of a balanced expression of kappa and lambda light chains on B lymphocytes, a polyclonal rearrangement of the IGH genes and the presence of an organized, round or oval-shaped, network of CD21+ dendritic cells, favors the diagnosis of "pseudolymphoma". Rather, an imbalance of kappa and lambda Ig light chain expression, a clonal rearrangement of IGH genes and the presence of an unstructured network of CD21+ dendritic cells favor the diagnosis of lymphoma.

In our experience, like the experience of others, the immunophenotypic study by flow cytometry of the lymphoid cells derived from skin biopsy is useful in helping to distinguish between reactive lymphoid hyperplasia and cutaneous B-cell lymphoma, as well as to identify the monoclonal B-cells, often with abnormal immunophenotype. . $^{27,38}$

Primary cutaneous B-cell lymphoma subtypes

Clinical manifestations are obviously not sufficient to make the diagnosis of PCBCL, but type and location of lesions may give some indication. Primary cutaneous follicle center lymphoma manifests more frequently in head and neck regions, while PCMZL predominantly affects trunk and limbs. Presence of nodules and/or single or multiple tumors in the legs should constitute a suspicion of PCLBCL-leg type, especially when the patient is an aged woman. ${ }^{39,40}$

The immunophenotypic profile of neoplastic B-cells, documented by immunohistochemistry and/ or flow cytometry, is crucial for the differential diagnosis (Chart 2).

Other B-cell lymphomas

Follicular lymphoma (FL): Skin involvement can occur in systemic FL, so it is important to estab- 
CHART 2: Immunophenotypic characteristics of the neoplastic B-cells in primary cutaneous B-cell lymphomas

\begin{tabular}{|llllllll|}
\hline & CD19 & & & & & & \\
& CD20 & CD5 & CD10 & BCL-6 & BCL-2 & MUM1 & FOXP1 \\
\hline PCMZL & + & - & - & - & $+(1)$ & $-(3)$ & - \\
PCFCL & + & - & $-/+$ & + & $-/+(2)$ & - & $-/+$ \\
PCLBCL,leg type & + & - & - & $-/+$ & $++(1)$ & + & + \\
& & & & & & & \\
\end{tabular}

Abbreviations: BCL-2, B-cell lymphoma 2; BCL-6, B-cell lymphoma 6; MUM1/IRF4, Multiple Myeloma 1 / Interferon Regulatory Factor 4 protein; FOXP1, Forkhead Box Protein P1; PCFCL, primary cutaneous follicle center cell lymphoma; PCLBCL, primary cutaneous large B-cell lymphomas, leg type; PCMZL, primary cutaneous marginal zone lymphomas.

(1) $\mathfrak{t}(14 ; 18)$ negative; (2) $t(14 ; 18)$ negative and BCL2 negative in the majority of cases; (3) Plasma cells are MUM1+.

lish the differential diagnosis. ${ }^{41}$ Head and neck are the most commonly affected regions in both cases. The positivity for CD10 and BCL2 and the presence of $t(14,18)$ are more frequent in cases of secondary skin involvement by systemic FL than in PCFCL. BCL6 is positive in both cases. ${ }^{41}$

Mantle cell lymphoma (MCL): Skin involvement by MCL is rare and usually secondary ${ }^{42}$ Histopathological skin examination shows infiltration in the dermis and subcutaneous tissue by atypical lymphoid cells positive for CD20, CD5, CD43 and cyclin $\mathrm{D} 1$, but negative for CD10 and CD23.

B-cell chronic lymphocytic leukemia (B-CLL): Like MCL, B-CLL may also involve skin. ${ }^{43-45}$ B-CLL lymphocytes are $\mathrm{CD} 5+$, but different from what happens with MCL, they are also CD23 and CD200 positive, and do not express cyclin D1.

Waldenström's macroglobulinemia: This disease is characterized by an expansion of clonal B-cells with plasmacytoid differentiation, which produces large amounts of IgM and infiltrates bone marrow, lymph nodes and spleen. Cutaneous manifestations are diverse and may consist of urticaria and purpuric rashes, ulcers, bullous lesions and vasculitis. ${ }^{46,47}$

Plasma cell neoplasms: Cutaneous plasmacytomas can be primary (no extra-cutaneous disease) or secondary and, in the latter case, they arise in patients with plasma cell myeloma or plasma cell leukemia, and rarely may be the first clinical manifestation of the disease. ${ }^{48}$ In plasma cell myeloma, hyperkeratotic spicules can be observed, preferably in the face..$^{49-51}$
Lymphomatoid granulomatosis: This is a rare extranodal B-cell lymphoproliferative disorder, systemic, angiocentric and destructive, which involves various organs and tissues, especially lungs, nervous system and skin. ${ }^{52}$ It associates with EBV infection and may progress to a large B-cell lymphoma.

Burkitt's lymphoma: It's an aggressive B-cell neoplasm that may secondarily involve the skin. In its endemic form, it occurs in children from Central Africa, where in most cases it associates with EBV infection. Sporadic cases observed in Europe and the United States may be associated or not to EBV and may occur in HIV infected patients. ${ }^{53}$

\section{LABORATORY TESTS}

In PCBCL, analytical or imaging changes attributable to lymphoma are not expected to occur at diagnosis. However, laboratory tests should be performed for two reasons: to confirm that it is a PCBCL and not a secondary skin involvement by a systemic lymphoma; and to exclude associated diseases, as it may be crucial for therapeutic decisions. ${ }^{54}$

In general, it is advisable to perform a complete blood cell count with leukocyte differential and a biochemical study, which should include liver and kidney analysis, measurement of serum levels of beta2-microglobulin, an indicator of tumor mass, and lactate dehydrogenase (LDH), an indicator of tumor lysis. If leukemic blood involvement is suspected (lymphocytosis, atypical lymphocytes) at diagnosis or during disease progression, the immunophenotypic study of peripheral blood lymphocytes should be performed.

Additional tests for staging include chest radiography and abdominal ultrasound. In patients with PCLCBL and in cases with advanced skin disease, 
thoracic, abdominal and pelvic computed tomography (CT) should be also done. A bone marrow (BM) biopsy, preferentially complemented with lymphocyte immunophenotyping by flow cytometry, is mandatory to exclude BM involvement; however, it can be dispensed in PCBCL with good prognosis (e.g. PCMZL), with typical clinical presentation and limited skin lesions. If adenomegalies are present, these should be investigated, preferably with excisional biopsy, in order to exclude extracutaneous lymphoma and/or nodal involvement by cutaneous lymphoma. Histopathological and immunohistochemical studies should be supplemented by flow cytometry-based immunophenotyping when possible.

\section{BIOLOGICAL ENTITIES}

At least three entities were described, which differs from the biological point of view and in clinical and laboratory characteristics (Chart 3). phomas

Primary cutaneous marginal zone B-cell lym-

Primary cutaneous marginal zone B-cell lymphomas (PCMZL) are extranodal marginal zone B-cell lymphomas, originating from MALT, more specifically from SALT. They represent about $10 \%$ of all PCL, showing indolent clinical behavior and excellent prognosis, with survival rate in 5 years exceeding 95\%.55-60 They can develop from reactive lymphoid infiltrates and, in some cases, pathogenic relationship with Borrelia burgdorferi infection has been suspected. ${ }^{12,14}$ Primary cutaneous immunocytoma and primary cutaneous plasmacytoma were considered PCMZL variants.

Clinically, PCMZL usually manifests in the form of solitary or multiple erythematous or violaceous papules, plaques, nodules or tumors, often located on trunk and limbs, and more rarely, in head and neck region. ${ }^{58,59}$ Secondary anetoderma, which results from the destruction of cutaneous elastic fibers and is often accompanied by the presence of anti-phospholipid antibodies in the serum, is more frequently observed in PCMZL, but can also occur in PCFCL. ${ }^{61-64}$

Histological findings include non-epidermotropic nodular or diffuse infiltrates, consisting of small or medium size lymphocytes, with an indented nucleus and a pale cytoplasm (marginal zone B-cells or monocytoid B-cells), and relatively abundant lymphoplasmacytoid cells. ${ }^{65}$ Reminiscent reactive germinal centers, often colonized by B-cells tumor and monoclonal (kappa or lambda+) plasma cells, are often located at the periphery of infiltrates. ${ }^{65,66} \mathrm{In}$ addition, aggregates of plasmacytoid cells are often present and these cells may exhibit cytoplasmic inclusions positive for periodic acid-Schiff (PAS), commonly referred to as "Dutcher bodies". Cases with large num- bers of lymphoplasmacytic cells and plasma cells with Dutcher bodies are designated as "cutaneous imunocytomas". ${ }^{35}$ There is also a variable number of reactive T-cells and, in contrast to that observed in most other PCBCL, aggregates of CD123+ plasmacytoid dendritic cells are relatively frequent. ${ }^{67}$

The phenotype of B-cells tumor, documented by immunohistochemical studies, includes positivity for CD19, CD20, CD22, CD43, CD79a, BCL2 and KiM1p (monocytoid B-cells), and negativity for CD5, CD10, CD23 and BCL6. In the reminiscent reactive germinal centers, B-cells do express CD10, BCL-6 and BCL-2, and plasma cells are CD138+ and CD79a+, but do not express CD20.

In our experience, the immunophenotypic study of B lymphocytes that infiltrate the skin, by flow cytometry, generally discloses a variable expansion of monoclonal (kappa or lambda+), CD19+, CD20+, CD5-, CD10- B-cells, as well as a polyclonal B-cell background, and also a few monoclonal plasma cells.

Analysis of IGH gene rearrangements generally shows a clonal pattern. ${ }^{68}$ Some rare cases with $\mathrm{t}(18$ 14) (q32,q21) (IGH/MALT1) and $t(3 ; 14)$ (p14.1;q32) (FOXP1/IGH) have been described. ${ }^{69,70}$ However, other chromosomal translocations found in MALT lymphomas involving MALT1 genes - $t(11 ; 18)(q 21, q 21)$ (API2/MALT1) and $\mathrm{t}(14 ; 18)$ (q32,q21) (IGH/MALT1) - are not observed in PCMZL, so cytogenetic studies have very limited value in the diagnosis. ${ }^{29,71,72}$

Two subtypes of PCMZL were proposed based on having or not Ig heavy chain class switching: those with IgM expression (non-switched) and those with IgG expression (switched). In IgG+ cases, lymphoid infiltrate is often rich in T-cells (CD4>CD8), usually presenting a nodular infiltration pattern. B cells typically do not express CXCR3, and an increase in mast cells is uncommon. Extracutaneous disease manifestations are also rare. In contrast, IgM+ cases generally have a predominance of B-cells, which often express CXCR3, and extracutaneous disease is relatively frequent. $^{73}$

Although the association with Borrelia burgdorferi infection has been described in single cases and series of patients in PCMZL have been published, documenting this association and leading to the hypothesis of a pathogenic relationship between this infection and the development of lymphoma, other studies did not support this hypothesis..$^{13,15-18}$

\section{Primary cutaneous follicle center B-cell lym- phomas \\ Primary cutaneous follicle center B-cell lym- phomas (PCFCL) originate from B-cells in the ger- minal centers of lymphoid follicles and contribute to about $10 \%$ of PCL. Like PCMZL, they have an ex-}


CHART 3: Main characteristics of the major primary cutaneous B-cell lymphomas subtypes

\begin{tabular}{|c|c|c|c|}
\hline & PCMZL & PCFCL & PCDLBCL, leg type \\
\hline Age & Adults (sometimes young) & Adults & Adults (old women+) \\
\hline Sex & $\mathrm{F}=\mathrm{M}$ & $\mathrm{F}=\mathrm{M}$ & $\mathrm{F}>\mathrm{M}$ \\
\hline Skin lesions & $\begin{array}{l}\text { Solitary or multiple reddish, dome- } \\
\text { shaped papules, nodules, or erythe- } \\
\text { matous plaques }\end{array}$ & $\begin{array}{l}\text { Solitary or multiple nodules } \\
\text { and/or tumors of firm con- } \\
\text { sistency, non-ulcerated }\end{array}$ & $\begin{array}{l}\text { Solitary or multiple } \\
\text { nodules and/or tu- } \\
\text { mors }\end{array}$ \\
\hline Preferential location & Trunk and limbs & Head and neck & Legs \\
\hline Associated conditions & $\begin{array}{l}\text { Anetoderma (some cases) } \\
\text { Borrelia burgdorferi (some cases) }\end{array}$ & - & - \\
\hline Histopathology & $\begin{array}{l}\text { Non-epidermotropic nodular or dif- } \\
\text { fuse infiltrates }\end{array}$ & $\begin{array}{l}\text { Non-epidermotropic nodu- } \\
\text { lar or diffuse infiltrates }\end{array}$ & $\begin{array}{l}\text { Non-epidermotropic } \\
\text { diffuse infiltrates }\end{array}$ \\
\hline Cytopathology & $\begin{array}{l}\text { Small or medium size lymphocytes, } \\
\text { with an indented nucleus and a pale } \\
\text { cytoplasm (marginal zone B-cells or } \\
\text { monocytoid B-cells), lymphoplasma- } \\
\text { cytoid cells, plasma cells }\end{array}$ & $\begin{array}{l}\text { Centrocytes, with some cen- } \\
\text { troblasts and immunoblasts }\end{array}$ & $\begin{array}{l}\text { Centroblasts or im- } \\
\text { munoblasts }\end{array}$ \\
\hline Immunohistochemistry & $\begin{array}{l}\text { CD20+, CD79a+, } \\
\text { BCL2+, BCL6- } \\
\text { MUM1- (+ plasma cells) } \\
\text { KiM1p+ } \\
\text { CD10- } \\
\text { CD5-, Cyclin D1- }\end{array}$ & $\begin{array}{l}\text { CD20+, CD79a+ } \\
\text { BCL2-/+, BCL6+ } \\
\text { MUM1- } \\
\text { KiM1p- } \\
\text { CD10- } \\
\text { CD5-, Cyclin D1 }\end{array}$ & $\begin{array}{l}\text { CD20+, CD79a+ } \\
\text { BCL2+, BCL6+/- } \\
\text { MUM1+ } \\
\text { KiM1p- } \\
\text { CD10- } \\
\text { CD5-, Cyclin D1- }\end{array}$ \\
\hline IGH rearrangements & Clonal in the majority of cases & Clonal & Clonal \\
\hline $\begin{array}{l}\text { Chromosomal transloca- } \\
\text { tions }\end{array}$ & $\mathrm{t}(14 ; 18)$ absent & $\mathrm{t}(14 ; 18)$ present in some cases & $\begin{array}{l}t(14 ; 18) \text { absent } \\
t(9 ; 21) \text { present in the } \\
\text { majority of cases }\end{array}$ \\
\hline Genes & & & $\begin{array}{l}\text { Losses in the 9p21 re- } \\
\text { gion (CDKN2A gene: } \\
\text { proteins p16/INK4 } \\
\text { and p14/ARF). } \\
\text { Gains in the } \\
\text { 18q21.31-q21.33 re- } \\
\text { gion (BCL2 and } \\
\text { MALT1 genes) }\end{array}$ \\
\hline Cutaneous relapse & Frequent & Frequent & Frequent \\
\hline $\begin{array}{l}\text { Extracutaneous dissem- } \\
\text { ination }\end{array}$ & Very rare & Rare $(5-10 \%)$ & Frequent \\
\hline 5-year survival rate & $>95 \%$ & $>90 \%$ & $<60 \%$ \\
\hline
\end{tabular}

Abbreviations: PCFCL, primary cutaneous follicle center cell lymphoma; PCLBCL, primary cutaneous large B-cell lymphomas, leg type; ; PCMZL, primary cutaneous marginal zone lymphomas; F, females; M, males; BCL-2, B-cell lymphoma 2; BCL-6, B-cell lymphoma 6; MUM1/IRF4, Multiple Myeloma 1 / Interferon Regulatory Factor 4 protein; INK4, inhibitor of kinase 4), CDK4, cyclin dependent kinase 4; ARF, Alternate open Reading Frame. $\left({ }^{*}\right)$ MUM1+ nos plasma cells. 
cellent prognosis, with a survival rate in 5 years exceeding $90 \%$; likewise, cutaneous relapse occurs very commonly and extracutaneous dissemination is very rare. ${ }^{39,74}$ They are also known as "Crosti's lymphomas", in honor of Crosti, who described in 1951 a number of patients with disfiguring erythematous plaques and nodules, giving it the designation of "reticulohistiocytoma" ${ }^{75}$ In general, PCFCL manifests by nodules and/or tumors of firm consistency, non-ulcerated, in the head and neck region, but may also occur in other body areas. ${ }^{39}$

From the histological point of view, three growth patterns were described: follicular, follicular and diffuse, and diffuse, the latter being the most common. The lymphoid infiltrate is composed primarily of cells with morphology of centrocytes, with some centroblasts and immunoblasts. The sub-epidermal "Grenz zone" is spared in most cases. In contrast to that typically found in reactive lymphoid infiltrates, mitoses are rare observed and macrophages are rarely seen. ${ }^{76}$

Neoplastic B lymphocytes are CD19+, CD20+, CD22+, CD79a+, CD5-, CD23+/-, CD43+, BCL6+ and $\mathrm{BCL2}-/+$. CD10 is expressed predominantly in cases of follicular growth pattern. Expression of BCL2 is variable, being observed in less than half of the cases, and correlating with the presence of $t(14 ; 18)(q 32, q 21)$ and rearrangement of BCL2. ${ }^{76,77} \mathrm{MUM} / \mathrm{IRF} 4$ antigen, which is positive in PCLBCL, is not expressed in PCF$\mathrm{CL}$ and may be useful for differentiating these entities when a diffuse growth pattern is observed. The network of CD21+ follicle dendritic cells is irregular.

From a molecular standpoint, there is a clonal rearrangement of IGH genes. Unlike what happens in nodal follicular lymphoma, $\mathrm{t}(14 ; 18)(\mathrm{q} 32, \mathrm{q} 21)$ and the corresponding BCL2 gene rearrangement is rarely observed.$^{76,77}$ Cases manifesting in the legs and cases with FOXP1 expression seem to have a worse prognosis and should be treated more aggressively. ${ }^{40}$

\section{Primary cutaneous large B-cell lymphomas}

Primary cutaneous large B-cell lymphomas (PCLBCL) account for approximately $6 \%$ of all PCL. They have a more aggressive behavior and poorer prognosis than other PCBCL, with a survival rate in 5 years of $20-55 \%$, tending to spread to lymphnodes and other extracutaneous sites. ${ }^{78-80}$ They are further classified into two groups: "leg type" and "others".

\section{leg type}

Primary cutaneous large B-cell lymphomas,

PCLBCL-leg type usually manifests by nodules or tumors, single or multiple, localized in one anatomic region. They are more common in older wom- en and, as the name implies, skin lesions are more common in the legs. This type has a great tendency to relapse as well as to spread extracutaneously, including to regional lymph nodes. Location in the legs and existence of multiple lesions were identified as poor prognostic factors in multivariate analysis. The lymphoma usually responds to treatment with R-CHOP (cyclophosphamide, hydroxidoxorrubicin, vincristine and prednisone + rituximab), but relapses are very common and treatment is not curative.

From the histological point of view, there is a diffuse infiltrate composed of large lymphoid cells, with morphology of centroblasts or immunoblasts, occupying the dermis and extending to the subcutaneous tissue, the sub-epidermal zone being usually spared. ${ }^{78}$ Centrocytes and CD21+ follicle dendritic cells, which are usually observed in PCFCL, are not present in PCLBCL. The characteristic immunophenotype is CD19+, CD20+, CD22+, CD79a+, BCL 2+, MUM1+, BCL6-/+, CD5-, CD10-, CD138-, and Cyclin D1-. The strong positivity for BCL2 and MUM1 helps to differentiate these lymphomas from PCFCL with diffuse growth pattern. ${ }^{80}$

Molecular studies confirm the clonal rearrangement of the IGH gene and, despite strong expression of BCL2, $\mathrm{t}(14,18)(\mathrm{q} 32, \mathrm{q} 21)$ and corresponding BCL2/ $\mathrm{JH}$ rearrangement are not observed. ${ }^{81} \mathrm{In}$ addition, gene expression profile differs from that observed in PCFCL. $33,34,82$ others

Primary cutaneous large B-cell lymphomas,

In this group we can find a wide variety of large B-cell lymphomas - in fact, all those who do not meet criteria for the diagnosis of PCLBCL-leg type. ${ }^{83-85}$ They are intravascular large B-cell lymphomas, plasmablastic lymphomas, T-cell and histiocyte rich large B-cell lymphomas, and CD30+ anaplastic large B-cell lymphomas, among others. ${ }^{85-108}$

\section{Intravascular large B-cell lymphomas}

Intravascular large B-cell lymphoma (IVLBCL) is a subtype of large B-cell lymphoma that is characterized by the accumulation of neoplastic B-cells in blood vessels. They often affect central nervous system, lungs and skin and generally have a poor prognosis. ${ }^{85}$ Although they may be primary skin involvement, the disease is usually widespread. Clinically it manifests as purplish patches and plaques or telangiectatic lesions, often located on legs or trunk. ${ }^{85}$ In some cases, the lymphoma arises in cutaneous angiomatous lesions. ${ }^{86,87}$ Prognosis is usually better in cases where the presentation is cutaneous than in cases with other forms of presentation (survival rate in 3 years of $56 \%$ versus $22 \%) .{ }^{85}$ From the histological point of view, di- 
lated blood vessels, filled by neoplastic large B-cells, are observed in dermis and subcutaneous tissue. ${ }^{85}$ Treatment consists of chemotherapy, even when the presentation is cutaneous. ${ }^{85}$

Other cutaneous large B-cell lymphomas

Plasmablastic lymphomas are aggressive lymphomas that usually occur in immunocompromised patients, particularly in HIV-infected patients and transplant recipients, and often manifest in the oral cavity. They have been described to be associated with EBV and, more recently, with HHV8. ${ }^{9,88-91}$ Neoplastic B-cells have a plasmablastic morphology and there is phenotypic evidence for terminal B-cell differentiation, with frequent positivity for CD38, CD138, MUM1 and EMA (epithelial membrane antigen) and absence of expression of CD20 and CD79. ${ }^{2,93}$ As in malignant plasma cells from patients with plasma cell myeloma, CD56 is frequently aberrantly expressed in the neoplastic plasmablasts, and aberrant CD10 expression may also be found..$^{2}$ Only a few cases of cutaneous plasmablastic lymphomas were published. ${ }^{94-105}$ Most of them occurred in immunocompromised patients, either HIV infected or post-transplant, ${ }^{94-101}$ although some cases also have been described in patients without evidence of imunossupression. ${ }^{102-105}$

T-cell and histiocyte rich large B-cell lymphomas are rare (1-2\% of lymphomas), and may have a nodal or extranodal presentation. Primary cutaneous forms are very rare, with only a few documented cases in the literature. ${ }^{106,107}$ They deserve special mention, as neoplastic B-cells are minimally represented, which can cause problems in diagnosis.

CD30+ anaplastic large B-cell lymphomas also deserve special attention, since they have not been individualized as an independent entity, but its features seem to be different. A retrospective study of 10 cases revealed that these lymphomas, which have an excellent prognosis, usually manifest as single skin lesions, affect elderly individuals and are more frequent in women; in addition, there is quite often a history of previous treatment with methotrexate. ${ }^{108}$ Diagnosis is often difficult because reactive T-cells may predominate, sometimes with a granulomatous reaction. The neoplastic B-cells often have immunoblastic features, and are positive for CD20, CD30, CD43 and BCL2, with frequent EBV infection.

\section{STAGING}

TNM classification used for PCTCL, mycosis fungoid (MF) and Sezary syndrome (SS) type, revised in $2007,{ }^{109}$ is not suitable for PCBCL. So in that same year, EORTC proposed a TNM system adapted for cutaneous lymphomas not MF/SS (Chart 4). ${ }^{110}$ This scheme was subsequently validated by clinical and pathological studies, but it is complex and difficult to apply in clinical practice. ${ }^{39,40}$ Factors considered for staging include the number and size of skin lesions; the number of affected body regions and the fact that they are or are not contiguous; the number of nodal regions involved and if they are central or peripheral, draining or not skin areas affected by the lymphoma.

\section{PROGNOSIS}

In general, PCBCL have a more indolent clinical course and a more favorable prognosis than their nodal counterparts. Tumor type and degree of cutaneous involvement are the most important prognostic factors. ${ }^{2,6,111}$

Overall survival rate in 5 years for PCMZL and PCFCL is higher than $90 \%$. In contrast, for PCLBCL, particularly leg type, prognosis is more guarded, with a survival rate in 5 years lower than $60 \%$. In all cases, cutaneous recurrences are frequent, but in PCMZL and in PCFCL types the disease usually remains localized to the skin, while in PCLBCL, especially leg type, extracutaneous dissemination is relatively common.

Given the good prognosis, patients with indolent PCMZL and PCFCL should be observed from the clinical point of view every 6 months, analysis and radiological examinations being justified only if there is evidence of disease progression, whereas patients with PCLBCL should be closely monitored (i.e., monthly or quarterly).

\section{TREATMENT}

Treatment should be selected taking into account the type of lymphoma and its stage, and should be adapted to risk. ${ }^{4,7,112}$ (Chart 5)

Several therapeutic modalities are available for PCBCL (Chart 6). ${ }^{56,113-142}$ However, indications are based mainly on retrospective studies (case reports or case series), with notable lack of randomized controlled trials that help to support clinical decisions. Generally, the consensus is that: a) aggressive treatment of indolent PCBCL (PCMZL or PCFCL) should be avoided, as they have a very good prognosis; $b$ ) chemotherapy is indicated in PCLBCL-leg type and in patients with advanced forms of PCMZL or PCFCL, which are resistant to other treatments and/or have extracutaneous disease spread. phomas

Treatment for indolent cutaneous B-cell lym-

In patients with PCMZL or PCFCL, treatment is different as there is a single skin lesion or a small number of lesions confined to one region or two adjacent regions, or where there are multiple skin lesions. ${ }^{54,143-145}$ In the first case, the options are surgical excision or 
CharT 4: TNM classification for cutaneous lymphomas non-Mycosis Fungoid, non-Sezary Syndrome proposed by the ISCL and the Cutaneous Lymphoma Task Force of the EORTC

\begin{tabular}{|ll|}
\hline T (tumor)† & T1: Single cutaneous lesion \\
& T1a: Single cutaneous lesion $<5 \mathrm{~cm}$ \\
T1b: Single cutaneous lesion $>5 \mathrm{~cm}$ \\
T2: Regional skin involvement (multiple lesions limited to one region or two contiguous regions) \\
T2a: All lesions - Diameter: $<15 \mathrm{~cm}$ \\
T2b: All lesions - Diameter: $15-30 \mathrm{~cm}$ \\
T2c: All lesions - Diameter: $>30 \mathrm{~cm}$ \\
T3: Generalized skin involvement \\
T3a: Multiple lesions involving 2 non-contiguous regions \\
T3b: Multiple lesions involving $\geq 3$ regions \\
N (nodules) t† \\
N0: No clinical or pathologic LN involvement \\
N1: Involvement of one peripheral LN region that drains an area of current or prior skin involvement \\
N2: Involvement of two or more peripheral LN or involvement of any LN region that does not drain \\
an area of current or prior skin involvement \\
N3: Involvement of central LN \\
M0: No evidence of extracutaneous non-LN disease \\
M1 (metastasis)
\end{tabular}

Definition of body regions (limits): Head and neck (inferior border - superior border of clavicles, T1 spinous process); Chest (superior border-superior border of clavicles; inferior border -inferior margin of rib cage; lateral borders - mid-axillary lines, gleno-humeral joints, inclusive of axillae). Abdomen / genital (superior border-inferior margin of rib cage; inferior border-inguinal folds, anterior perineum; lateral borders-mid-axillary lines). Upper back (superior border-T1 spinous process; inferior border - inferior margin of rib cage; lateral borders - mid-axillary lines). Lower back / buttocks (superior border-inferior margin of rib cage; inferior border - inferior gluteal fold, anterior perineum, inclusive of perineum; lateral borders-mid-axillary lines). Each upper arm (superior borders - glenohumeral joints, exclusive of axillae; inferior borders - ulnar/radial-humeral / elbow joint). Each lower arm/hand (superior borders - ulnar/ radial-humeral / elbow joint. Each upper leg, thigh (superior borders - inguinal folds, inferior gluteal folds; inferior borders - mid-patellae, mid-popliteal fossae). Each lower leg, foot (superior borders-mid-patellae, mid-popliteal fossae).

Definition of LN regions (Ann Arbor system): Peripheral LN: antecubital, cervical, supraclavicular, axillary, inguinal-femoral, and popliteal. Central LN: mediastinal, pulmonary hilar, paraortic, iliac.

Abbreviations: ISCL, International Society for Cutaneous Lymphomas; EORTC European Organization of Research and Treatment of Cancer. Source: Kim YH et al, $2007^{110}$

CHART 5: Main treatment modalities for primary cutaneous B cell lymphomas

\begin{tabular}{|lll|}
\hline PCMZL & PCFCL & PCLBCL, leg type \\
\hline $\begin{array}{l}\text { Radiotherapy, surgery, rituximab, } \\
\text { IFN-alpha2a. }\end{array}$ & $\begin{array}{l}\text { Radiotherapy, surgery, rituximab, } \\
\text { IFN-alpha2a. }\end{array}$ & Polychemotherapy (CHOP, R-CHOP). \\
$\begin{array}{l}\text { Polychemotherapy (CHOP, R-CHOP) } \\
\text { reserved for patients with advanced } \\
\text { and/or resistant cutaneous disease or } \\
\text { extra-cutaneous involvement. }\end{array}$ & $\begin{array}{l}\text { Polychemotherapy (CHOP, R-CHOP) } \\
\text { reserved for patients with advanced } \\
\text { and/or resistant cutaneous disease or } \\
\text { extra-cutaneous involvement. }\end{array}$ & $\begin{array}{l}\text { Radiotherapy or surgery for solitary } \\
\text { lesions, IFN-alpha or rituximab as ad- } \\
\text { juvant therapy or for patients unfit for } \\
\text { chemotherapy. }\end{array}$ \\
\hline
\end{tabular}

Abbreviations: PCMZL, primary cutaneous marginal zone lymphomas; PCFCL, primary cutaneous follicle center cell lymphoma; PCLBCL, primary cutaneous large B cell lymphomas; IFN, Interferon; CHOP: cyclophosphamide, doxorubicin, oncovin (vincristine) and prednisone, every 21 days, 6 - 8 courses; R-CHOP, CHOP with rituximab. 
CHART 6: Therapeutic schemas for cutaneous B-cell lymphomas

\begin{tabular}{|c|c|c|}
\hline Therapy & Description & References \\
\hline \multirow{2}{*}{ Antibiotics } & Doxicicline, $100 \mathrm{mg}$, 2xday, 3 weeks & 56 \\
\hline & Cefotaxime, i.v. & 113 \\
\hline Local radiotherapy & $\begin{array}{l}\text { Orthovoltage radiotherapy (20-100 kV). Cumulative dose per irradiation } \\
\text { field: } 15 \text { to } 45 \mathrm{~Gy} \text { ( } 2.0 \text { to } 2.5 \mathrm{~Gy} / \text { week, fractionated). Margins ranging from } \\
1 \text { to } 5 \mathrm{~cm} \text {. }\end{array}$ & $114-118 ; 146-149$ \\
\hline Corticosteroids & Corticosteroids, intralesional & 119 \\
\hline \multirow[t]{2}{*}{ Monoclonal antibodies } & $\begin{array}{l}\text { Rituximab, intralesional, } 2 \text { to } 3 \text { times weekly, } 10 \text { to } 30 \mathrm{mg} / \text { dose/ lesion, } \\
\text { depending on the size, } 4 \text { to } 8 \text { consecutive weeks. }\end{array}$ & $120-124$ \\
\hline & Rituximab, i.v., $375 \mathrm{mg} / \mathrm{m} 2,1 \times$ week, 4 weeks. & $125-131$ \\
\hline Immunomoduladors & Interferon alpha 2a, intralesional, 3 - 9 million units, 3 x week. & $132-136$ \\
\hline Monochemotherapy & Peguilated liposomal doxorrubicin ( $20-40 \mathrm{mg} / \mathrm{m} 2$, i.v., every 2 to 4 weeks) & 137 \\
\hline $\begin{array}{l}\text { Monochemotherapy }+ \\
\text { monoclonal antibodies }\end{array}$ & $\begin{array}{l}\text { Peguilated liposomal doxorrubicin }(20-40 \mathrm{mg} / \mathrm{m} 2 \text {, i.v., every } 2 \text { weeks })+ \\
\text { rituximab }(375 \mathrm{mg} / \mathrm{m} 2)\end{array}$ & 138 \\
\hline Polychemotherapy & $\begin{array}{l}\text { CHOP (cyclophosphamide, doxorrubicin, oncovin }=\text { vincristine e } \\
\text { prednisone), every } 21 \text { days, } 6 \text { courses }\end{array}$ & 80,139 \\
\hline $\begin{array}{l}\text { Polychemotherapy }{ }^{+} \\
\text {monoclonal antibodies }\end{array}$ & $\mathrm{CHOP}+$ rituximab & $140-142$ \\
\hline
\end{tabular}

radiotherapy. In the second case, the options consist mainly of antibiotics, monoclonal antibodies (mAbs) (i.e., rituximab, an anti-CD20 $\mathrm{mAb}$ ) and interferons (i.e. interferon alpha 2a, IFN-alpha2a).

\section{Radiotherapy}

In general, in patients undergoing radiation therapy, cumulative dose per field ranges from $15 \mathrm{~Gy}$ to $45 \mathrm{~Gy}$, generally fractionated into doses of $2 \mathrm{~Gy}$ to 2.5 Gy per irradiation field per week, and usually including a margin of $1 \mathrm{~cm}$ to $5 \mathrm{~cm}$ of normal skin around the affected skin. Most of the patients have a complete response (CR), while recurrence occurs in about half of cases (Table 1). . $^{54,80,115-118,145-150}$

A retrospective study of 32 patients with PCBCL classified according to the EORTC schema - PCFCL (21 cases; 66\%); PCMZL (4 cases/ 13\%); and PCLBCL-leg type (3 cases; $9 \%$ ) - treated with local radiotherapy (median dose: 40 Gy ranging from 20 Gy to 48 Gy) revealed a $100 \%$ CR rate, an overall survival rate in 5 years of $96 \%$ (67\% in PCLBCL-leg type and $100 \%$ in the remaining cases), a disease-free survival rate in 5 years of $55 \%$ (33\% in patients with PCLBCL-leg type and from $62 \%$ to $73 \%$ in other types). In 5 years, $21 \%$ of patients (33\% of PCLBCL-leg type) had extracuta- neous disease. ${ }^{118}$

Another retrospective study of 153 patients with PCBCL (101 with PCFCL; 25 with PCMZL; and 27 with PCLBCL-leg type) treated with radiotherapy showed an overall response (OR) rate of $100 \%$ and a CR rate of $99 \%$, with rates of recurrence of $60 \%, 29 \%$ and $64 \%$ for PCMZL, PCFCL and PCLBCL, respectively. ${ }^{149}$

\section{Rituximab}

Although published studies are all retrospective and therefore uncontrolled and non-randomized, there seems to be evidence that rituximab induces lasting remission in indolent PCBCL (PCMZL or PCFCL), without appreciable adverse events. ${ }^{151}$ Schemes for intravenous or intralesional administration of rituximab used in these studies were relatively similar, with some variations in dose and schedule of administration, and total number of doses (Tables 2 and 3). ${ }^{120-131,152-159}$

\section{Intravenous rituximab}

A search via PubMed allowed identifying 16 papers published in journals indexed in MEDLINE between 2000 and 2013 that reported the use of intravenous rituximab, as monotherapy for the treatment of 
TABLE 1: Radiotherapy for primary cutaneous B-cell lymphomas

\begin{tabular}{|c|c|c|c|c|c|c|c|c|c|c|}
\hline \multirow[t]{2}{*}{ Reference } & \multirow{2}{*}{$\begin{array}{l}\text { Number of } \\
\text { patients }\end{array}$} & \multicolumn{4}{|c|}{ Lymphoma classification } & \multicolumn{4}{|c|}{ Response to treatment } & \multirow{2}{*}{$\begin{array}{l}\text { Complementary } \\
\text { information }\end{array}$} \\
\hline & & PCFCL & PCMZL & PCLBCL & Other & $\overline{\text { OR }}$ & CR & PR & NR & \\
\hline 146 & $35(100 \%)$ & $21(60 \%)$ & $7(20 \%)$ & $4(11 \%)$ & $3(9 \%)$ & $35(100 \%)$ & $35(100 \%)$ & $0(0 \%)$ & $0(0 \%)$ & $\begin{array}{l}\text { Median follow-up } 11 \\
\text { months: } 11 \text { (31\%) relapses. } \\
\text { Median follow-up } 52 \\
\text { months, } 27(77 \%) \text { alive; } 8 \\
(23 \%) \text { death (3 with lym- } \\
\text { phoma). } \\
\text { 5-year survival rate: } 75 \% \text {. } \\
\text { Free disease 5-year surviv- } \\
\text { al rate: } 50 \% \text {. }\end{array}$ \\
\hline 118 & $32(100 \%)$ & $21(66 \%)$ & $4(13 \%)$ & $3(9 \%)$ & $0(0 \%)$ & $32(100 \%)$ & $32(100 \%)$ & $0(0 \%)$ & $0(0 \%)$ & $\begin{array}{l}\text { 5-year survival rate: PCL- } \\
\text { BCL, leg type }(67 \%) \text {; other } \\
\text { PCBCL }(100 \%) \text {. } \\
\text { Free disease } 5 \text {-year sur- } \\
\text { vival: PCLBCL, leg type } \\
(33 \%) \text {; other PCBCL }(73 \%) \text {. } \\
\text { Follow-up } 5 \text { years: } 21 \% \\
\text { with extracutaneous dis- } \\
\text { ease }\end{array}$ \\
\hline 149 & $153(100 \%)$ & $101(66 \%)$ & $25(16 \%)$ & $27(18 \%)$ & $0(0 \%)$ & $153(100 \%)$ & $151(99 \%)$ & $2(1 \%)$ & $0(0 \%)$ & $\begin{array}{l}\text { 5-year survival rate: PCF- } \\
\text { CL (95\%); PCMZL ( } 97 \%) \text {; } \\
\text { PCLBCL, leg type (59\%) } \\
\text { Relapse rate: PCMZL } \\
(60 \%) \text { PCFCL (29\%); PCL- } \\
\text { BCL (64\%); PCLBCL, leg } \\
\text { type (63\%) } \\
\text { PCFCL with skin lesions in } \\
\text { the legs: relapse rate (63\%); } \\
5 \text {-year survival (44\%) } \\
\text { PCFCL with skin lesions in } \\
\text { other body regions: relapse } \\
\text { rate (25\%); 5-year survival } \\
\text { (99\%) }\end{array}$ \\
\hline Total & $220(100 \%)$ & $143(65 \%)$ & $36(16 \%)$ & $34(15 \%)$ & $3(1 \%)$ & $220(100 \%)$ & $218(99 \%)$ & $2(1 \%)$ & $0(0 \%)$ & \\
\hline
\end{tabular}

Abbreviations: PCBCL, primary cutaneous B-cell lymphoma; PCFCL, primary cutaneous follicle center cell lymphoma; PCLBCL, primary cutaneous large B-cell lymphomas, leg type; PCMZL, primary cutaneous marginal zone lymphomas; OR, overall response; CR, complete response; PR, partial response; NR, no response. 
TABLE 2: Intravenous rituximab for the treatment of primary cutaneous B-cell lymphomas

\begin{tabular}{|c|c|c|c|c|c|c|c|c|c|c|}
\hline \multirow[t]{2}{*}{ References } & \multirow{2}{*}{$\begin{array}{l}\text { Number of } \\
\text { patients }\end{array}$} & \multicolumn{4}{|c|}{ Lymphoma classification } & \multicolumn{4}{|c|}{ Response to treatment } & \multirow[t]{2}{*}{ Complementary information } \\
\hline & & PCFCL & PCMZL & $\begin{array}{l}\text { PCLBCL- } \\
\text { leg type }\end{array}$ & $\begin{array}{l}\text { PCLBCL, } \\
\text { other }\end{array}$ & OR & CR & PR & NR & \\
\hline 120 & 10 & 3 & 0 & 6 & 1 & 8 & 6 & 2 & 2 & \\
\hline 125 & 2 & 0 & 0 & 1 & 1 & 2 & 0 & 2 & 0 & \\
\hline 126 & 4 & 2 & 2 & 0 & 0 & 4 & 2 & 2 & 0 & $\begin{array}{l}\text { Maintenance therapy with rituximab } \\
\text { every } 4 \text { weeks for } 6 \text { months }\end{array}$ \\
\hline 127 & 10 & 8 & 1 & 1 & 0 & 9 & 7 & 2 & 1 & $\begin{array}{l}\text { Median remission time: } 23 \text { months ( } 4 \text { - } \\
30 \text { months). }\end{array}$ \\
\hline 128 & 5 & 3 & 1 & 0 & 1 & 5 & 5 & 0 & 0 & $\begin{array}{l}\text { Maintenance therapy with rituximab } \\
\text { every } 2 \text { or } 3 \text { months in some patients. } \\
\text { Follow-up: } 17 \text { - } 66 \text { months. One patient } \\
\text { died in complete remission } 66 \text { months } \\
\text { later; one patient developed a PCLBCL } \\
3 \text { years later. }\end{array}$ \\
\hline 129 & 15 & 10 & 5 & 0 & 0 & 13 & 9 & 4 & 2 & $\begin{array}{l}\text { Median times of follow-up, time to re- } \\
\text { sponse, duration of response and time } \\
\text { to progression: } 36,30 \text {, } 24 \text { e } 24 \text { months. }\end{array}$ \\
\hline 130 & 16 & 11 & 5 & 0 & 0 & 16 & 14 & 2 & 0 & $\begin{array}{l}\text { Five of the } 14 \text { patients with CR ( } 35 \%) \\
\text { relapsed, after } 6 \text { to } 37 \text { months }\end{array}$ \\
\hline 131 & 18 & 11 & 2 & 5 & 0 & 16 & 16 & 0 & 2 & $\begin{array}{l}\text { Mean follow-up time: } 52 \text { months. Re- } \\
\text { lapse } 81 \% \text { of cases. Median time to } \\
\text { relapse: } 25 \text { months. The patients that } \\
\text { were refractory to rituximab had PCL- } \\
\text { BCL, leg type. }\end{array}$ \\
\hline 152 & 2 & 2 & 0 & 0 & 0 & 2 & 1 & 1 & 0 & $\begin{array}{l}\text { Disease progression after } 6 \text { and } 17 \\
\text { months, respectively. }\end{array}$ \\
\hline 153 & 2 & 2 & 0 & 0 & 0 & 2 & 2 & 0 & 0 & \\
\hline 154 & 2 & 1 & 0 & 1 & 0 & 2 & 2 & 0 & 0 & $\begin{array}{l}\text { No relapses during a follow-up of } 24 \\
\text { and } 17 \text { months, respectively. }\end{array}$ \\
\hline 155 & 1 & 1 & 0 & 0 & 0 & 1 & 1 & 0 & 0 & \\
\hline 156 & 2 & 1 & 1 & 0 & 0 & 2 & 2 & 0 & 0 & $\begin{array}{l}\text { No relapses during a follow-up of } 18 \\
\text { and } 24 \text { months, respectively. }\end{array}$ \\
\hline 157 & 1 & 0 & 1 & 0 & 0 & 1 & 1 & 0 & 0 & Relapse after 13 months. \\
\hline 158 & 1 & 1 & 0 & 0 & 0 & 1 & 1 & 0 & & \\
\hline 159 & 11 & 11 & 0 & 0 & 0 & 11 & 7 & 4 & 0 & $\begin{array}{l}\text { Median follow-up time: } 30 \text { months (9 } \\
\text { - } 65 \text { months). Relapse: } 6 \text { cases. Median } \\
\text { time to relapse: } 23.6 \text { months. }\end{array}$ \\
\hline Total & $\begin{array}{l}102 \\
(100 \%)\end{array}$ & $\begin{array}{l}67 \\
(66 \%)\end{array}$ & $\begin{array}{l}18 \\
(18 \%)\end{array}$ & $\begin{array}{l}14 \\
(14 \%)\end{array}$ & $\begin{array}{l}3 \\
(3 \%)\end{array}$ & $\begin{array}{l}95 \\
(93 \%\end{array}$ & $\begin{array}{l}76 \\
(75 \%)\end{array}$ & $\begin{array}{l}19 \\
(19 \%\end{array}$ & $\begin{array}{l}7 \\
(7 \%)\end{array}$ & \\
\hline
\end{tabular}

Rituximab was administered intravenously, $375 \mathrm{mg} / \mathrm{m} 2$, once weekly, 4 to 8 consecutive weeks.

Abbreviations: PCBCL, primary cutaneous B-cell lymphoma; PCFCL, primary cutaneous follicle center cell lymphoma; PCLBCL, primary cutaneous large B-cell lymphomas, leg type; PCMZL, primary cutaneous marginal zone lymphomas; OR, overall response; CR, complete response; PR, partial response; NR, no response. 
TABLE 3: Intralesional rituximab for primary cutaneous B-cell lymphomas

\begin{tabular}{|c|c|c|c|c|c|c|c|c|c|c|}
\hline \multirow[t]{2}{*}{ References } & \multirow{2}{*}{$\begin{array}{l}\text { Number of } \\
\text { patients }\end{array}$} & \multicolumn{4}{|c|}{ Lymphoma classification } & \multicolumn{4}{|c|}{ Response to treatment } & \multirow{2}{*}{$\begin{array}{l}\text { Complementary } \\
\text { information }\end{array}$} \\
\hline & & PCFCL & PCMZL & $\begin{array}{l}\text { PCLBCL- } \\
\text { leg type }\end{array}$ & $\begin{array}{l}\text { PCLBCL, } \\
\text { other }\end{array}$ & OR & CR & PR & NR & \\
\hline 120 & 2 & 1 & 0 & 1 & 0 & 2 & 0 & 2 & 0 & \\
\hline 121 & 3 & 3 & 0 & 0 & 0 & 3 & 3 & 0 & 0 & $\begin{array}{l}\text { One patient repeated the } \\
\text { treatment. Complete and } \\
\text { prolonged response ( }>1 \\
\text { year) in all cases. }\end{array}$ \\
\hline 122 & 2 & 0 & 2 & 0 & 0 & 2 & 2 & 0 & 0 & $\begin{array}{l}\text { Follow-up time: } 22 \text { and } 36 \\
\text { months. Relapse in } 1 \text { case } \\
\text { after } 22 \text { months. }\end{array}$ \\
\hline 123 & 1 & 1 & 0 & 0 & 0 & 1 & 1 & 0 & 0 & No relapse at 6 months \\
\hline 124 & 35 & 18 & 17 & 0 & 0 & 33 & 25 & 8 & 2 & $\begin{array}{l}\text { Mean time to remission: } 8 \\
\text { weeks. Median follow-up } \\
\text { time: } 21 \text { months. Medi- } \\
\text { an disease free time: } 114 \\
\text { months }\end{array}$ \\
\hline 153 & 7 & 3 & 4 & 0 & 0 & 7 & 6 & 1 & 0 & $\begin{array}{l}\text { Follow-up time: } 12 \text { to } 27 \\
\text { months. Relapse in } 3 / 6 \text { cas- } \\
\text { es (12, } 14 \text { and } 27 \text { months, } \\
\text { respectively). }\end{array}$ \\
\hline 156 & 6 & 3 & 3 & 0 & 0 & 6 & 6 & 0 & 0 & $\begin{array}{l}\text { Median follow-up time: } 6 \\
\text { months ( } 3-14 \text { months). Re- } \\
\text { lapse in } 4 / 6 \text { cases. Median } \\
\text { time to relapse: } 6 \text { months }\end{array}$ \\
\hline Total & $56(100 \%)$ & $29(52 \%)$ & $26(46 \%)$ & $1(2 \%)$ & $0(0 \%)$ & $54(96 \%)$ & $43(77 \%)$ & $11(20 \%)$ & $2(3 \%)$ & \\
\hline
\end{tabular}

Rituximab was administered intralesional, 10 to $30 \mathrm{mg} /$ lesion/session, 1 to 3 times weekly, 4 to 8 consecutive weeks or 1 week month, 4 to 8 eight consecutive months.

Abbreviations: PCBCL, primary cutaneous B-cell lymphoma; PCFCL, primary cutaneous follicle center cell lymphoma; PCLBCL, primary cutaneous large B-cell lymphomas, leg type; PCMZL, primary cutaneous marginal zone lymphomas; OR, overall response; CR, complete response; PR, partial response; NR, no response. 
PCBCL in a total of 102 patients (Table 2). ${ }^{120,125-131,152-159} \mathrm{In}$ general, the dose was $375 \mathrm{mg} / \mathrm{m}^{2} / \mathrm{administration}$, being repeated weekly for 4 to 8 weeks, and responses were obtained in 95 cases (93\%), with CR in 76 cases (75\%).

\section{Intralesional rituximab}

Another search via PubMed revealed 7 papers published in journals indexed in MEDLINE between 2000 and 2012, in which rituximab was administered intralesional for the treatment of PCBCL (Table 3). ${ }^{120-}$ ${ }^{124,153,156}$ In total, 56 patients were treated with rituximab monotherapy (26 patients with PCMZL, 19 patients with PCFCL and 1 patient with PCLBCL). Dose (in general, $10 \mathrm{mg}$ to $30 \mathrm{mg} /$ lesion/session, depending on the size of the lesion), frequency of administration (usually 1 to 3 times a week) and intervals between them (usually 4 to 8 consecutive weeks or 1 week per month for 4 to 8 months) were variable. Fifty-four cases $(96 \%)$ responded to treatment, with CR in 43 cases (77\%).

\section{Adverse events}

In general, rituximab is well tolerated. Local adverse effects reported after intralesional administration include, in addition to pain at the injection site, other rare manifestations such as rash, pruritus, urticaria, bacterial infections, lichenoid reactions, paraneoplastic pemphigus, toxic epidermal necrolysis (Stevens-Johnson syndrome) and bullous dermatitis. Rare cases of urticaria reaction at lymphoma lesion were also reported after intravenous administration of rituximab. ${ }^{120,155}$ Systemic events include anaphylactic reactions and reactivation of viral infections, including hepatitis B, arrhythmias, vasculitis, mucositis, arthralgia and arthritis. ${ }^{160-164}$

\section{Interferon alpha 2a}

Interferon-alpha2a, a cytokine capable of modulating the progression of the cell cycle and induce apoptosis with a significant anti-tumor activity, has been successfully used in the treatment of PCTCL and can be considered as a potential therapeutic alternative for PCBCL. ${ }^{165,166}$ However, there are only a few published studies on the use of IFN-alpha2a for treatment of PCBCL.

\section{Intralesional interferon alfa $2 \mathrm{a}$}

A search via PubMed revealed only 5 papers published in journals indexed in MEDLINE between 1989 and 2006, reporting on the use of intralesional IFN-alfa2a for the treatment of 12 patients with PCB$\mathrm{CL}$, most of them PCMZL, and a CR was obtained in all cases (Table 4). ${ }^{132-134,136}$ The dose ranged from 3 to 9 million/ units/ session and the sessions were repeated 3 times a week for several months, in some cases for 1 year.

\section{Subcutaneous interferon-alpha2a}

Reports on the use of subcutaneous IFN-alpha2a for the treatment of PCBCL are even more scarce, with only a few cases reported. ${ }^{167-169}$ In our experience, which is based on the treatment of 6 patients with PCMZL of whom only 2 cases were targeted for publication, PCMZL respond well to IFN-alpha2a administered subcutaneously at a dose of 3 million units, 3 times a week, until maximum response, which usually happens after a variable time (median: 6 months). ${ }^{167,169}$ Complete response was observed in all patients, with a median duration of remission of 9 months. Relapses were frequent, occurring in $50 \%$ of cases. Patients with recurrence repeated treatment with IFN-alfa2a successfully. A case of a patient with PCFCL who achieved complete response after being treated with IFN-alpha2a administered subcutaneously, 4.5 million units, 3 times a week, was recently published. ${ }^{168}$

\section{Treatment for aggressive cutaneous B-cell lymphomas}

Patients with PCLBCL, particularly leg type - which have more aggressive clinical behavior and poor prognosis - are candidates to treatment with multidrug therapy with CHOP (cyclophosphamide, doxorubicin, vincristine, and prednisone) or CHOPlike regimens. ${ }^{80,139}$ In elderly patients, it should be advisable to reduce the doses of doxorubicin $(25 \mathrm{mg} /$ $\left.\mathrm{m}^{2}\right)$, vincristine $\left(1 \mathrm{mg} / \mathrm{m}^{2}\right)$ and cyclophosphamide $\left(400 \mathrm{mg} / \mathrm{m}^{2}\right)$ with the goal of having less cardiac and hematological toxicity. ${ }^{142}$ The association of rituximab to the chemotherapy (e.g. R-CHOP) appears to result in increased benefit compared to chemotherapy alone, evaluated by the increase in the survival time. ${ }^{140}$ Rituximab monotherapy leads to response rates lower than those observed with chemotherapy, and relapse appears to occur earlier, but can be used for palliative treatment. ${ }^{141}$

Pegylated liposomal doxorubicin used successfully in the treatment of PCTCL in a dose from $20 \mathrm{mg} /$ $\mathrm{m}^{2}$ to $40 \mathrm{mg} / \mathrm{m}^{2}$, administered intravenously and repeated every 2 to 4 weeks, may be considered an alternative for the treatment of PCBCL having been used alone or in combination with rituximab, with appreciable response rates, good tolerance and low hematological toxicity. ${ }^{137-139}$

A study in which 5 patients with PCBCL (1 with PCMZL and 4 with PCLBCL-leg-type) with disseminated skin lesions) were treated with pegylated liposomal doxorubicin at a dose of $20 \mathrm{mg} / \mathrm{m}^{2}$ showed CR in $100 \%$ of cases. ${ }^{137}$ In follow-up, one patient died with disease progression and 4 patients maintained CR after 5, 52, 63 and 69 months, respectively.

Another recent study in which 12 patients PCL- 
TABLE 4: Intralesional interferon alpha 2a for primary cutaneous B-cell lymphomas

\begin{tabular}{|c|c|c|c|c|c|c|c|c|c|c|}
\hline \multirow[t]{2}{*}{ References } & \multirow{2}{*}{$\begin{array}{l}\text { Number of } \\
\text { patients }\end{array}$} & \multicolumn{4}{|c|}{ Lymphoma classification } & \multicolumn{4}{|c|}{ Response to treatment } & \multirow{2}{*}{$\begin{array}{l}\text { Complementary } \\
\text { information }\end{array}$} \\
\hline & & PCFCL & PCMZL & $\begin{array}{l}\text { PCLBCL- } \\
\text { leg type }\end{array}$ & $\begin{array}{l}\text { PCLBCL, } \\
\text { other }\end{array}$ & OR & CR & PR & NR & \\
\hline 132 & 1 & 0 & 0 & 0 & 1 & 1 & 1 & 0 & 0 & $\begin{array}{l}\text { One patient with PCLBCL } \\
\text { (transformation of an indo- } \\
\text { lent PCBCL) refractory to } \\
\text { chemotherapy }\end{array}$ \\
\hline 133 & 1 & 0 & 1 & 0 & 0 & 1 & 1 & 0 & 0 & $\begin{array}{l}\text { One patient with PCMZL } \\
\text { associated to Borrelia burg- } \\
\text { dorferi infection resistant } \\
\text { treatment of cefotaxime }\end{array}$ \\
\hline & & & & & & & & & & $\begin{array}{l}\text { One patient with T-cell rich } \\
\text { PCLBCL }\end{array}$ \\
\hline 134 & 1 & 0 & 0 & 0 & 1 & 1 & 1 & 0 & 0 & $\begin{array}{l}\text { One patient with PCMZL, } \\
\text { stage IVa }\end{array}$ \\
\hline 135 & 1 & 0 & 1 & 0 & 0 & 1 & 1 & 0 & 0 & $\begin{array}{l}\text { Eight patients with PCM- } \\
\text { ZL. Median time to com- } \\
\text { plete response: } 8.5 \text { weeks } \\
\text { (3 to } 20 \text { weeks). Relapses }\end{array}$ \\
\hline 136 & 8 & 0 & 8 & 0 & 0 & 8 & 8 & 0 & 0 & $\begin{array}{l}\text { in } 2 \text { cases, after } 4 \text { and } 12 \\
\text { weeks, respectively }\end{array}$ \\
\hline Total & $12(100 \%)$ & $0(0 \%)$ & $10(83 \%)$ & $0(0 \%)$ & $2(17 \%)$ & $12(100 \%)$ & $12(100 \%)$ & $0(0 \%)$ & $0(0 \%)$ & \\
\hline
\end{tabular}

Interferon alpha-2a was administered intralesional, 3 to 9 millions of units, 3 times weekly, during several months.

Abbreviations: PCBCL, primary cutaneous B-cell lymphoma; PCFCL, primary cutaneous follicle center cell lymphoma; PCLBCL, primary cutaneous large B-cell lymphomas, leg type; PCMZL, primary cutaneous marginal zone lymphomas; OR, overall response; CR, complete response; PR, partial response; NR, no response.

BCL were treated with pegylated liposomal doxorubicin $\left(20 \mathrm{mg} / \mathrm{m}^{2}\right.$ on days 1 and 15$)$ associated with rituximab $\left(375 \mathrm{mg} / \mathrm{m}^{2}\right)$ showed response in 10 of 12 patients (8 CR and 2 PR) - 2 out of 3 patients with PCLBCL-leg type. Two patients relapsed at 31 and 32 months, respectively. ${ }^{138}$

A relatively common side effect associated with the administration of liposomal doxorubicin, which may also arise with other chemotherapy regimens, is the palmoplantar erythrodysesthesia, also known as "hand-foot-syndrome", which is characterized by painful acral (palmoplantar) erythema. ${ }^{170-172}$ Coldness during administration of chemotherapy, topical application of high potency corticosteroids and prophylactic administration of pyridoxine orally are some of the recommended measures to control the associated symptoms. ${ }^{172}$ 


\section{REFERENCES}

1. Newton R, Ferlay J, Beral V, Devesa SS. The epidemiology of non-Hodgkin's lymphoma: comparison of nodal and extra-nodal sites. Int J Cancer. 1997;72:92330 .

2. Bradford PT, Devesa SS, Anderson WF, Toro JR. Cutaneous lymphoma incidence patterns in the United States: a population-based study of 3884 cases. Blood. 2009;113:5064-73.

3. Sokol L, Naghashpour M, Glass LF. Primary cutaneous B-cell lymphomas: recent advances in diagnosis and management. Cancer Control. 2012;19:236-44.

4. Swerdlow SH, Quintanilla-Martinez L, Willemze R, Kinney MC. Cutaneous B-cell lymphoproliferative disorders: report of the 2011 Society for Hematopathology/ European Association for Haematopathology workshop. Am J Clin Pathol. 2013:139:515-35.

5. Wilcox RA. Cutaneous B-cell lymphomas: 2013 update on diagnosis, riskstratification, and management. Am J Hematol. 2013;88:73-6.

6. Kempf W, Kazakov DV, Mitteldorf C. Cutaneous lymphomas: an update. Part 2: B-cell lymphomas and related conditions. Am J Dermatopathol. 2014;36:197208.

7. Suárez AL, Pulitzer M, Horwitz S, Moskowitz A, Querfeld C, Myskowski PL. Primary cutaneous B-cell lymphomas: part I. Clinical features, diagnosis, and classification. J Am Acad Dermatol. 2013;69:329.e1-13.

8. Suárez AL, Querfeld C, Horwitz S, Pulitzer M, Moskowitz A, Myskowski PL. Primary cutaneous B-cell lymphomas: part II. Therapy and future directions. J Am Acad Dermatol. 2013;69:343.e1-11.

9. Burg G, Kempf W, Cozzio A, Feit J, Willemze R, S Jaffe E, et al. WHO/EORTC classification of cutaneous lymphomas 2005: histological and molecular aspects. J Cutan Pathol. 2005;32:647-74.

10. Willemze R, Jaffe ES, Burg G, Cerroni L, Berti E, Swerdlow SH, et al. WHO-EORTC classification for cutaneous lymphomas. Blood. 2005;105:3768-85.

11. Swerdlow SH, International Agency for Research on Cancer. WHO Classification of tumours of haematopoietic and lymphoid tissues. Lyon: International Agency for Research on Cancer; 2008.

12. Carbone A, Cesarman E, Spina M, Gloghini A, Schulz TF. HIV-associated lymphomas and gamma-herpesviruses. Blood. 2009;113:1213-24.

13. Michaelis S, Kazakov DV, Schmid M, Dummer R, Burg G, Kempf W. Hepatitis C and $G$ viruses in B-cell lymphomas of the skin. J Cutan Pathol. 2003;30:369-72.

14. Viguier M, Rivet J, Agbalika F, Kerviler E, Brice P, Dubertret L, et al. B-cell lymphomas involving the skin associated with hepatitis $\mathrm{C}$ virus infection. Int $\mathrm{J}$ Dermatol. 2002;41:577-82.

15. Garbe C, Stein H, Dienemann D, Orfanos CE. Borrelia burgdorferi-associated cutaneous B-cell lymphoma: clinical and immunohistologic characterization of four cases. J Am Acad Dermatol. 1991;24:584-90.

16. Monari P, Farisoglio C, Calzavara Pinton PG. Borrelia burgdorferi-associated primary cutaneous marginal-zone B-cell lymphoma: a case report. Dermatology. 2007:215:229-32.

17. Bahler DW, Kim BK, Gao A, Swerdlow SH. Analysis of immunoglobulin V genes suggests cutaneous marginal zone B-cell lymphomas recognise similar antigens. Br J Haematol. 2006;132:571-5.

18. Colli C, Leinweber B, Müllegger R, Chott A, Kerl H, Cerroni L. Borrelia burgdorferiassociated lymphocytoma cutis: clinicopathologic, immunophenotypic, and molecular study of 106 cases. J Cutan Pathol. 2004;31:232-40.

19. Takino H, Li C, Hu S, Kuo TT, Geissinger E, Muller-Hermelink HK, et al. Primary cutaneous marginal zone B-cell lymphoma: a molecular and clinicopathological study of cases from Asia, Germany, and the United States. Mod Pathol. 2008;21:1517-26.

20. Goteri G, Ranaldi R, Simonetti 0, Capretti R, Menzo S, Stramazzotti D, et al. Clinicopathological features of primary cutaneous B-cell lymphomas from an academic regional hospital in central Italy: no evidence of Borrelia burgdorferi association. Leuk Lymphoma. 2007;48:2184-8.

21. Ponzoni M, Ferreri AJ, Mappa S, Pasini E, Govi S, Facchetti F, et al. Prevalence of Borrelia burgdorferi infection in a series of 98 primary cutaneous lymphomas. Oncologist. 2011;16:1582-8.

22. Viraben $R$, Brousse $P$, Lamant $L$. Reversible cutaneous lymphoma occurring during methotrexate therapy. Br J Dermatol. 1996;135:116-8.

23. Fam AG, Perez-Ordonez B, Imrie K. Primary cutaneous B-cell lymphoma during methotrexate therapy for rheumatoid arthritis. J Rheumatol. 2000;27:1546-9.

24. Tournadre A, D'Incan M, Dubost JJ, Franck F, Déchelotte P, Souteyrand P, et al. Cutaneous lymphoma associated with Epstein-Barr virus infection in 2 patients treated with methotrexate. Mayo Clin Proc. 2001;76:845-8.

25. Giard C, Avenel-Audran M, Croué A, Verret JL, Martin L. Primary cutaneous Epstein-Barr virus-associated B-cell lymphoma arising at the site of subcutaneous injections of methotrexate. J Clin Oncol. 2010;28:e717-8.

26. Burg G, Braun-Falco 0, Hoffmann-Fezer G, Rodt H, Schmoeckel C. Patterns of cutaneous lymphomas. Histological, enzyme cytochemical, and immunological typing of lymphoreticular proliferations in the skin. Dermatologica. 1978;157:28291.

27. Wu JM, Vonderheid E, Gocke CD, Moresi JM, Liegeois N, Borowitz MJ Flow cytometry of lesional skin enhances the evaluation of cutaneous B-cell lymphomas. J Cutan Pathol. 2012;39:918-28.

28. Xie X, Sundram U, Natkunam Y, Kohler S, Hoppe RT, Kim YH, et al. Expression of HGAL in primary cutaneous large B-cell lymphomas: evidence for germinal center derivation of primary cutaneous follicular lymphoma. Mod Pathol. 2008;21:653-9.

29. de la Fouchardiere A, Gazzo S, Balme B, Chouvet B, Felman P, Coiffier B, et al. Cytogenetic and molecular analysis of 12 cases of primary cutaneous marginal zone lymphomas. Am J Dermatopathol. 2006;28:287-92.

30. Dijkman R, Tensen $\mathrm{CP}$, Buettner M, Niedobitek G, Willemze R, Vermeer MH. Primary cutaneous follicle center lymphoma and primary cutaneous large B-cell lymphoma, leg type, are both targeted by aberrant somatic hypermutation but demonstrate differential expression of AID. Blood. 2006;107:4926-9.

31. Belaud-Rotureau MA, Marietta V, Vergier B, Mainhaguiet G, Turmo M, Idrissi Y, et al. Inactivation of p16INK4a/CDKN2A gene may be a diagnostic feature of large B-cell lymphoma leg type among cutaneous B-cell lymphomas. Virchows Arch. 2008;452:607-20.

32. Kaune KM, Neumann C, Hallermann C, Haller F, Schön MP, Middel P. Simultaneous aberrations of single CDKN2A network components and a high Rb phosphorylation status can differentiate subgroups of primary cutaneous B-cell lymphomas. Exp Dermatol. 2011;20:331-5.

33. Storz MN, van de Rijn M, Kim YH, Mraz-Gernhard S, Hoppe RT, Kohler S. Gene expression profiles of cutaneous B-cell lymphoma. J Invest Dermatol. 2003;120:865-70

34. Hoefnagel JJ, Dijkman R, Basso K, Jansen PM, Hallermann C, Willemze R, et al. Distinct types of primary cutaneous large B-cell lymphoma identified by gene expression profiling. Blood. 2005;105:3671-8.

35. Rijlaarsdam JU, Meijer CJ, Willemze R. Differentiation between lymphadenosis benigna cutis and primary cutaneous follicular center cell lymphomas. A comparative clinicopathologic study of 57 patients. Cancer. 1990;65:2301-6.

36. Burg G, Schmid MH, Küng E, Dommann S, Dummer R. Semimalignant ("pseudolymphomatous") cutaneous B-cell lymphomas. Dermatol Clin. 1994;12:399-407.

37. Schaerer L, Schmid MH, Mueller B, Dummer RG, Burg G, Kempf W. Angiogenesis in cutaneous lymphoproliferative disorders: microvessel density discriminates between cutaneous B-cell lymphomas and B-cell pseudolymphomas. Am J Dermatopathol. 2000;22:140-3.

38. Schafernak KT, Variakojis D, Goolsby CL, Tucker RM, Martínez-Escala ME, Smith FA, et al. Clonality Assessment of Cutaneous B-Cell Lymphoid Proliferations: A Comparison of Flow Cytometry Immunophenotyping, Molecular Studies, and Immunohistochemistry/In Situ Hybridization and Review of the Literature. Am J Dermatopathol. 2014;36:781-95.

39. Golling P, Cozzio A, Dummer R, French L, Kempf W. Primary cutaneous B-cell lymphomas - clinicopathological, prognostic and therapeutic characterisation of 54 cases according to the WHO-EORTC classification and the ISCL/EORTC TNM classification system for primary cutaneous lymphomas other than mycosis fungoides and Sezary syndrome. Leuk Lymphoma. 2008;49:1094-103.

40. Senff NJ, Hoefnagel JJ, Jansen PM, Vermeer MH, van Baarlen J, Blokx WA, et al. Reclassification of 300 primary cutaneous B-Cell lymphomas according to the new WHO-EORTC classification for cutaneous lymphomas: comparison with previous classifications and identification of prognostic markers. J Clin Oncol. 2007;25:1581-7.

41. Kim BK, Surti U, Pandya A, Cohen J, Rabkin MS, Swerdlow SH. Clinicopathologic, immunophenotypic, and molecular cytogenetic fluorescence in situ hybridization analysis of primary and secondary cutaneous follicular lymphomas. Am J Surg Pathol. 2005;29:69-82.

42. Motegi S, Okada E, Nagai Y, Tamura A, Ishikawa O. Skin manifestation of mantle cell Iymphoma. Eur J Dermatol. 2006;16:435-8.

43. Plaza JA, Comfere NI, Gibson LE, Colgan M, Davis DM, Pittelkow MR, et al. Unusual cutaneous manifestations of B-cell chronic lymphocytic leukemia. J Am Acad Dermatol. 2009;60:772-80.

44. Ali L, Cheney R, Merzianu M. Subclinical chronic lymphocytic leukemia with atypical cutaneous presentation. J Cutan Pathol. 2011;38:236-40.

45. Ratterman M, Kruczek K, Sulo S, Shanafelt TD, Kay NE, Nabhan C. Extramedullary chronic lymphocytic leukemia: systematic analysis of cases reported between 1975 and 2012. Leuk Res. 2014;38:299-303.

46. Oberschmid B, Siebolts U, Mechtel D, Kreibich U, Beller A, Wickenhauser C. M protein deposition in the skin: a rare manifestation of Waldenström macroglobulinemia. Int J Hematol. 2011;93:403-5.

47. Spicknall KE, Dubas LE, Mutasim DF. Cutaneous macroglobulinosis with monotypic 
plasma cells: a specific manifestation of Waldenström macroglobulinemia. $J$ Cutan Pathol. 2013:40:440-4.

48. Ballester-Martínez MA, González-García C, Fleta-Asín B, Burdaspal-Moratilla A, Santón-Roldán A, Jiménez-Gómez N, et al. Cutaneous nodules as a diagnostic clue in multiple myeloma. Am J Dermatopathol. 2013;35:377-80.

49. Bork K, Böckers M, Pfeifle J. Pathogenesis of paraneoplastic follicular hyperkeratotic spicules in multiple myeloma. Follicular and epidermal accumulation of IgG dysprotein and cryoglobulin. Arch Dermatol. 1990;126:509-13.

50. Requena L, Sarasa JL, Ortiz Masllorens F, Martín L, Piqué E, Olivares M, et al. Follicular spicules of the nose: a peculiar cutaneous manifestation of multiple myeloma with cryoglobulinemia. J Am Acad Dermatol. 1995;32:834-9.

51. Braun RP, Skaria AM, Saurat JH, Borradori L. Multiple hyperkeratotic spicules and myeloma. Dermatology. 2002;205:210-2.

52. Roschewski M, Wilson WH. Lymphomatoid granulomatosis. Cancer J. 2012;18:469-74.

53. Jacobson MA, Hutcheson AC, Hurray DH, Metcalf JS, Thiers BH. Cutaneous involvement by Burkitt lymphoma. J Am Acad Dermatol. 2006;54:1111-3.

54. Senff NJ, Noordijk EM, Kim YH, Bagot M, Berti E, Cerroni L, et al. European Organization for Research and Treatment of Cancer and International Society for Cutaneous Lymphoma consensus recommendations for the management of cutaneous B-cell lymphomas. Blood. 2008;112:1600-9.

55. Bailey EM, Ferry JA, Harris NL, Mihm MC Jr, Jacobson JO, Duncan LM. Marginal zone lymphoma (low-grade B-cell lymphoma of mucosa-associated lymphoid tissue type) of skin and subcutaneous tissue: a study of 15 patients. Am J Surg Pathol. 1996;20:1011-23.

56. Cerroni L, Signoretti S, Höfler G, Annessi G, Pütz B, Lackinger E, et al. Primary cutaneous marginal zone B-cell lymphoma: a recently described entity of low-grade malignant cutaneous B-cell lymphoma. Am J Surg Pathol. 1997;21:1307-15.

57. Pimpinelli N, Santucci M. The skin-associated lymphoid tissue-related B-cell Iymphomas. Semin Cutan Med Surg. 2000;19:124-9.

58. Kempf W, Ralfkiaer E, Duncan LM. Cutaneous marginal zone B-cell lymphoma. In: LeBoit P, Burg G, Weedon D. World Health Organization Classification of Tumours Pathology and Genetics of Skin Tumors. Lyon, France: WHO IARC; 2006. p. 194-5.

59. Isaacson $P G$, Chott $A$, Nakamura $S$. Extranodal marginal zone lymphoma of mucosa-associated lymphoid tissue (MALT lymphoma). In: Swerdlow SH, Campo E, Harris NL, Jaffe ES, Pileri SA, Stein H, et al, editors. World Health Organization Classification of Tumours of Haematopoietic and Lymphoid Tissues. 4th ed. Lyon, France: IARC Press; 2008. p. 214-7.

60. Dalle S, Thomas L, Balme B, Dumontet C, Thieblemont C. Primary cutaneous marginal zone lymphoma. Crit Rev Oncol Hematol. 2010;74:156-62.

61. Kasper RC, Wood GS, Nihal M, LeBoit PE. Anetoderma arising in cutaneous B-cell lymphoproliferative disease. Am J Dermatopathol. 2001;23:124-32.

62. Zattra E, Pigozzi B, Bordignon M, Marino F, Chiarion-Sileni V, Alaibac M. Anetoderma in cutaneous marginal-zone B-cell lymphoma. Clin Exp Dermatol. 2009;34:e945-8.

63. Hodak E, Feuerman H, Barzilai A, David M, Cerroni L, Feinmesser M. Anetodermic primary cutaneous B-cell lymphoma: a unique clinicopathological presentation of lymphoma possibly associated with antiphospholipid antibodies. Arch Dermatol. 2010;146:175-82.

64. Ferrara G, Cusano F, Robson A, Stefanato CM. Primary cutaneous marginal zone B-cell lymphoma with anetoderma: spontaneous involution plus de novo clonal expansion. J Cutan Pathol. 2011;38:342-5.

65. Tomaszewski MM, Abbondanzo SL, Lupton GP. Extranodal marginal zone B-cell lymphoma of the skin: a morphologic and immunophenotypic study of 11 cases. Am J Dermatopathol. 2000;22:205-11.

66. Takino H, Li C, Hu S, Kuo TT, Geissinger E, Muller-Hermelink HK, et al. Primary cutaneous marginal zone B-cell lymphoma: a molecular and clinicopathological study of cases from Asia, Germany, and the United States. Mod Pathol. 2008;21:1517-26.

67. Kutzner H, Kerl H, Pfaltz MC, Kempf W. CD123-positive plasmacytoid dendritic cells in primary cutaneous marginal zone B-cell lymphoma: diagnostic and pathogenetic implications. Am J Surg Pathol. 2009:33:1307-13

68. Child FJ, Woolford AJ, Calonje E, Russell-Jones R, Whittaker SJ. Molecular analysis of the immunoglobulin heavy chain gene in the diagnosis of primary cutaneous B-cell lymphoma. J Invest Dermatol. 2001;117:984-9.

69. Streubel B, Lamprecht A, Dierlamm J, Cerroni L, Stolte M, Ott G, et al. T(14;18) (q32;q21) involving IGH and MALT1 is a frequent chromosomal aberration in MALT Iymphoma. Blood. 2003;101:2335-9.

70. Streubel B, Vinatzer U, Lamprecht A, Raderer M, Chott A. T(3;14)(p14.1;q32) involving IGH and FOXP1 is a novel recurrent chromosomal aberration in MALT Iymphoma. Leukemia. 2005;19:652-8.

71. Schreuder MI, Hoefnagel JJ, Jansen PM, van Krieken JH, Willemze R, Hebeda KM. FISH analysis of MALT lymphoma-specific translocations and aneuploidy in primary cutaneous marginal zone lymphoma. J Pathol. 2005;205:302-10.
72. Gallardo F, Bellosillo B, Espinet B, Pujol RM, Estrach T, Servitje 0, et al. Aberrant nuclear BCL10 expression and lack of $t(11 ; 18)(q 21 ; q 21)$ in primary cutaneous marginal zone B-cell lymphoma. Hum Pathol. 2006;37:867-73.

73. Edinger JT, Kant JA, Swerdlow SH. Cutaneous marginal zone lymphomas have distinctive features and include 2 subsets. Am J Surg Pathol. 2010;34:1830-41.

74. Willemze R, Kerl H, Sterry W, Berti E, Cerroni L, Chimenti S, et al. EORTC classification for primary cutaneous lymphomas: a proposal from the Cutaneous Lymphoma Study Group of the European Organization for Research and Treatment of Cancer. Blood. 1997;90:354-71.

75. Berti E, Alessi E, Caputo R, Gianotti R, Delia D, Vezzoni P. Reticulohistiocytoma of the dorsum. J Am Acad Dermatol. 1988;19:259-72.

76. Cerroni L, Arzberger E, Pütz B, Höfler G, Metze D, Sander CA, et al. Primary cutaneous follicle center cell lymphoma with follicular growth pattern. Blood. 2000;95:3922-8.

77. Mirza I, Macpherson N, Paproski S, Gascoyne RD, Yang B, Finn WG, et al. Primary cutaneous follicular lymphoma: an assessment of clinical, histopathologic, immunophenotypic, and molecular features. J Clin Oncol. 2002;20:647-55.

78. Kodama K, Massone C, Chott A, Metze D, Kerl H, Cerroni L. Primary cutaneous large B-cell lymphomas: clinicopathologic features, classification, and prognostic factors in a large series of patients. Blood. 2005;106:2491-7.

79. Grange F, Beylot-Barry M, Courville P, Maubec E, Bagot M, Vergier B, et al. Primary cutaneous diffuse large B-cell lymphoma, leg type: clinicopathologic features and prognostic analysis in 60 cases. Arch Dermatol. 2007;143:1144-50.

80. Paulli M, Lucioni M, Maffi A, Croci GA, Nicola M, Berti E. Primary cutaneous diffuse large B-cell lymphoma (PCDLBCL), leg-type and other: an update on morphology and treatment. G Ital Dermatol Venereol. 2012;147:589-602.

81. Grønbaek K, Møller PH, Nedergaard T, Thomsen K, Baadsgaard 0, Hou-Jensen K, et al. Primary cutaneous B-cell lymphoma: a clinical, histological, phenotypic and genotypic study of 21 cases. Br J Dermatol. 2000;142:913-23.

82. Dijkman R, Tensen CP, Jordanova ES, Knijnenburg J, Hoefnagel JJ, Mulder AA, et al. Array-based comparative genomic hybridization analysis reveals recurrent chromosomal alterations and prognostic parameters in primary cutaneous large B-cell lymphoma. J Clin Oncol. 2006;24:296-305.

83. Dommann SN, Dommann-Scherrer CC, Zimmerman D, Dours-Zimmermann MT, Hassam S, Burg G. Primary cutaneous T-cell-rich B-cell lymphoma. A case report with a 13-year follow-up. Am J Dermatopathol. 1995;17:618-24.

84. Perniciaro C, Winkelmann RK, Daoud MS, Su WP. Malignantangioendotheliomatosis is an angiotropic intravascular lymphoma. Immunohistochemical, ultrastructural, and molecular genetics studies. Am J Dermatopathol. 1995;17:242-8.

85. Ferreri AJ, Campo E, Seymour JF, Willemze R, Ilariucci F, Ambrosetti A, et al. Intravascular lymphoma: clinical presentation, natural history, management and prognostic factors in a series of 38 cases, with special emphasis on the "cutaneous variant $\mathrm{Br} J$ Haematol. 2004;127:173-83.

86. Rubin MA, Cossman J, Freter CE, Azumi N. Intravascular large cell lymphoma coexisting within hemangiomas of the skin. Am J Surg Pathol. 1997;21:860-4.

87. Kobayashi T, Munakata S, Sugiura H, Koizumi M, Sumida M, Murata K, et al Angiotropic lymphoma: proliferation of B-cells in the capillaries of cutaneous angiomas. Br J Dermatol. 2000;143:162-4.

88. Flaitz CM, Nichols CM, Walling DM, Hicks MJ. Plasmablastic lymphoma: an HIVassociated entity with primary oral manifestations. Oral Oncol. 2002;38:96-102.

89. Castillo JJ, Reagan JL. Plasmablastic lymphoma: a systematic review. ScientificWorldJournal. 2011;11:687-96.

90. Hsi ED, Lorsbach RB, Fend F, Dogan A. Plasmablastic lymphoma and related disorders. Am J Clin Pathol. 2011;136:183-94.

91. Montes-Moreno S, Montalbán C, Piris MA. Large B-cell lymphomas with plasmablastic differentiation: a biological and therapeutic challenge. Leuk Lymphoma. 2012;53:185-94.

92. Colomo L, Loong F, Rives S, Pittaluga S, Martínez A, López-Guillermo A, et al. Diffuse large B-cell lymphomas with plasmablastic differentiation represent a heterogeneous group of disease entities. Am J Surg Pathol. 2004;28:736-47.

93. Vega F, Chang CC, Medeiros LJ, Udden MM, Cho-Vega JH, Lau CC, et al. Plasmablastic lymphomas and plasmablastic plasma cell myelomas have nearly identical immunophenotypic profiles. Mod Pathol. 2005;18:806-15.

94. Häusermann P, Khanna N, Buess M, Itin PH, Battegay M, Dirnhofer S, et al. Cutaneous plasmablastic lymphoma in an HIV-positive male: an unrecognized cutaneous manifestation. Dermatology. 2004;208:287-90.

95. Dales JP, Harket $A$, Bagnères $D$, Andrac-Meyer $L$, Xerri $L$, Frances $Y$, et al. Plasmablastic lymphoma in a patient with HIV infection: an unusual case located in the skin. Ann Pathol. $2005 ; 25: 45-9$.

96. Jordan LB, Lessells AM, Goodlad JR. Plasmablastic lymphoma arising at a cutaneous site. Histopathology. 2005;46:113-5.

97. Liu W, Lacouture ME, Jiang J, Kraus M, Dickstein J, Soltani K, et al. KSHV/ HHV8-associated primary cutaneous plasmablastic lymphoma in a patient with Castleman's disease and Kaposi's sarcoma. J Cutan Pathol. 2006;33:46-51. 
98. Jambusaria A, Shafer D, Wu H, Al-Saleem T, Perlis C. Cutaneous plasmablastic lymphoma. J Am Acad Dermatol. 2008;58:676-8.

99. Bernabeu-Wittel J, Gonzalo DH, Luque R, Borrero JJ, Conejo-Mir J. Cutaneous nodules as diagnostic key of an extraoral plasmablastic lymphoma in an human immunodeficiency virus-infected patient. J Eur Acad Dermatol Venereol. 2008;22:127-9.

100. Gong J, Alkan S, Anand S. A Case of Cutaneous Plasmablastic Lymphoma in HIV/ AIDS with Disseminated Cryptococcus. Case Rep Oncol Med. 2013;2013:862585.

101. Verma S, Nuovo GJ, Porcu P, Baiocchi RA, Crowson AN, Magro CM. Epstein-Barr virus- and human herpesvirus 8-associated primary cutaneous plasmablastic lymphoma in the setting of renal transplantation. J Cutan Pathol. 2005;32:35-9.

102. Heiser D, Müller H, Kempf W, Eisendle K, Zelger B. Primary cutaneous plasmablastic lymphoma of the lower leg in an HIV-negative patient. J Am Acad Dermatol. 2012;67:e202-5

103. Horna P, Hamill JR Jr, Sokol L, Glass LF. Primary cutaneous plasmablastic lymphoma in an immunocompetent patient. J Am Acad Dermatol. 2013;69:e2746.

104. Tiong IS, Strauss M, Lau MB, Chiruka S. Cutaneous plasmablastic lymphoma in an immunocompetent patient with long-term pyrimethamine use for essential thrombocythemia: a case report and literature review. Case Rep Hematol. 2013;2013:541783.

105. Eke U, Pratt G, Muc R, Heagerty A. Cutaneous plasmablastic lymphoma in a nonimmunocompromised patient. J Am Acad Dermatol. 2013;69:e315-7.

106. Venizelos ID, Tatsiou ZA, Mandala E. Primary cutaneous T-cell-rich B-cell lymphoma: a case report and literature review. Acta Dermatovenerol Alp Pannonica Adriat. 2008:17:177-81.

107. Vezzoli P, Fiorani R, Girgenti V, Fanoni D, Tavecchio S, Balice Y, et al. Cutaneous T-cell/histiocyte-rich B-cell lymphoma: a case report and review of the literature. Dermatology. 2011;222:225-30.

108. Magro CM, Nash JW, Werling RW, Porcu P, Crowson N. Primary cutaneous CD30+ large cell B-cell lymphoma: a series of 10 cases. Appl Immunohistochem Mol Morphol. 2006;14:7-11.

109. Olsen E, Vonderheid E, Pimpinelli N, Willemze R, Kim Y, Knobler R, et al. Revisions to the staging and classification of mycosis fungoides and Sezary syndrome: a proposal of the International Society for Cutaneous Lymphomas (ISCL) and the cutaneous lymphoma task force of the European Organization of Research and Treatment of Cancer (EORTC). Blood. 2007;110:1713-22.

110. Kim YH, Willemze R, Pimpinelli N, Whittaker S, Olsen EA, Ranki A, et al. TNM classification system for primary cutaneous lymphomas other than mycosis fungoides and Sezary syndrome: a proposal of the International Society for Cutaneous Lymphomas (ISCL) and the Cutaneous Lymphoma Task Force of the European Organization of Research and Treatment of Cancer (EORTC). Blood. 2007; $110: 479-84$.

111. Zinzani PL, Quaglino P, Pimpinelli N, Berti E, Baliva G, Rupoli S, et al. Prognostic factors in primary cutaneous B-cell lymphoma: the Italian Study Group for Cutaneous Lymphomas. J Clin Oncol. 2006;24:1376-82.

112. Hamilton SN, Wai ES, Tan K, Alexander C, Gascoyne RD, Connors JM. Treatment and outcomes in patients with primary cutaneous B-cell lymphoma: the BC Cancer Agency experience. Int J Radiat Oncol Biol Phys. 2013;87:719-25.

113. Kütting B, Bonsmann G, Metze D, Luger TA, Cerroni L. Borrelia burgdorferiassociated primary cutaneous B-cell lymphoma: complete clearing of skin lesions after antibiotic pulse therapy or intralesional injection of interferon alfa-2a. J Am Acad Dermatol. 1997;36:311-4.

114. Goldschmidt H. Radiation therapy of other cutaneous tumors. In: Goldschmidt H, Panizzon R. Modern Dermatologic Radiation Therapy. New York: Springer-Verlag; 1991. p. 123-32

115. Voss N, Kim-Sing C. Radiotherapy in the treatment of dermatologic malignancies. Dermatol Clin. 1998;16:313-20.

116. Kirova YM, Piedbois Y, Le Bourgeois JP. Radiotherapy in the management of cutaneous B-cell lymphoma. Our experience in 25 cases. Radiother Oncol. 1999;52:15-8.

117. Piccinno R, Caccialanza M, Berti E. Dermatologic radiotherapy of primary cutaneous follicle center cell lymphoma. Eur J Dermatol. 2003;13:49-52.

118. Smith BD, Glusac EJ, McNiff JM, Smith GL, Heald PW, Cooper DL, et al. Primary cutaneous B-cell lymphoma treated with radiotherapy: a comparison of the European Organization for Research and Treatment of Cancer and the WHO classification systems. J Clin Oncol. 2004;22:634-9.

119. Perry A, Vincent BJ, Parker SR. Intralesional corticosteroid therapy for primary cutaneous B-cell lymphoma. Br J Dermatol. 2010;163:223-5.

120. Heinzerling L, Dummer R, Kempf W, Schmid MH, Burg G. Intralesional therapy with anti-CD20 monoclonal antibody rituximab in primary cutaneous B-cell Iymphoma. Arch Dermatol. 2000;136:374-8.

121. Paul T, Radny P, Kröber SM, Paul A, Blaheta HJ, Garbe C. Intralesional rituximab for cutaneous B-cell lymphoma. Br J Dermatol. 2001;144:1239-43.
122. Kyrtsonis MC, Siakantaris MP, Kalpadakis C, Dimopoulou MN, Vassilakopoulos TP, Kontopidou FN, et al. Favorable outcome of primary cutaneous marginal zone lymphoma treated with intralesional rituximab. Eur J Haematol. 2006;77:300-3.

123. Gamo R, Calzado L, Pinedo F, López-Estebaranz JL. Cutaneous follicular center B-cell lymphoma treated with intralesional rituximab. Actas Dermosifiliogr. 2008:99:291-6.

124. Peñate Y, Hernández-Machín B, Pérez-Méndez LI, Santiago F, Rosales B, Servitje 0, et al. Intralesional rituximab in the treatment of indolent primary cutaneous B-cell lymphomas: an epidemiological observational multicentre study. The Spanish Working Group on Cutaneous Lymphoma. Br J Dermatol. 2012;167:174-9.

125. Sabroe RA, Child FJ, Woolford AJ, Spittle MF, Russell-Jones R. Rituximab in cutaneous B-cell lymphoma: a report of two cases. Br J Dermatol. 2000;143:15761.

126. Gellrich S, Muche JM, Pelzer K, Audring H, Sterry W. Anti-CD20 antibodies in primary cutaneous B-cell lymphoma. Initial results in dermatologic patients. Hautarzt. 2001;52:205-10.

127. Gellrich S, Muche JM, Wilks A, Jasch KC, Voit C, Fischer T, et al. Systemic eightcycle anti-CD20 monoclonal antibody (rituximab) therapy in primary cutaneous B-cell lymphomas--an applicational observation. Br J Dermatol. 2005;153:167-73.

128. Gitelson E, Al-Saleem T, Millenson M, Lessin S, Smith MR. Cutaneous B-cell lymphoma responds to rituximab: a report of five cases and a review of the literature. Leuk Lymphoma. 2006;47:1902-7.

129. Morales AV, Advani R, Horwitz SM, Riaz N, Reddy S, Hoppe RT, et al. Indolent primary cutaneous B-cell lymphoma: experience using systemic rituximab. J Am Acad Dermatol. 2008;59:953-7.

130. Valencak J, Weihsengruber F, Rappersberger K, Trautinger F, Chott A, Streubel B, et al. Rituximab monotherapy for primary cutaneous B-cell lymphoma: response and follow-up in 16 patients. Ann Oncol. 2009;20:326-30.

131. Brandenburg A, Humme D, Terhorst D, Gellrich S, Sterry W, Beyer M. Long-term outcome of intravenous therapy with rituximab in patients with primary cutaneous B-cell lymphomas. Br J Dermatol. 2013;169:1126-32.

132. Tourani JM, Leaute JB, Lessana-Leibowitch M, Andrieu JM. Complete remission following recombinant interferon alpha-2a in a patient with diffuse large B-cell cutaneous lymphoma. Nouv Rev Fr Hematol. 1989;31:315-6.

133. Kütting B, Bonsmann G, Metze D, Luger TA, Cerroni L. Borrelia burgdorferiassociated primary cutaneous B-cell lymphoma: complete clearing of skin lesions after antibiotic pulse therapy or intralesional injection of interferon alfa-2a. J Am Acad Dermatol. 1997;36:311-4.

134. Wollina U. Complete response of a primary cutaneous T-cell-rich B-cell lymphoma treated with interferon alpha2a. J Cancer Res Clin Oncol. 1998;124:127-9.

135. Wollina U, Hahnfeld S, Kosmehl H. Primary cutaneous marginal center lymphoma - complete remission induced by interferon alpha2a. J Cancer Res Clin Oncol. 1999;125:305-8.

136. Cozzio A, Kempf W, Schmid-Meyer R, Gilliet M, Michaelis S, Schärer L, et al. Intralesional low-dose interferon alpha2a therapy for primary cutaneous marginal zone B-cell lymphoma. Leuk Lymphoma. 2006;47:865-9.

137. Pulini S, Rupoli S, Goteri G, Pimpinelli N, Alterini R, Bettacchi A, et al. Efficacy and safety of pegylated liposomal doxorubicin in primary cutaneous B-cell lymphomas and comparison with the commonly used therapies. Eur J Haematol. 2009;82:184-93.

138. Fabbri A, Cencini E, Alterini R, Rubegni P, Rigacci L, Delfino C, et al. Rituximab plus liposomal pegylated doxorubicin in the treatment of primary cutaneous B-cell lymphomas. Eur J Haematol. 2014;93:129-36.

139. Sarris AH, Braunschweig I, Medeiros LJ, Duvic M, Ha CS, Rodriguez MA, et al. Primary cutaneous non-Hodgkin's lymphoma of Ann Arbor stage I: preferential cutaneous relapses but high cure rate with doxorubicin-based therapy. J Clin Oncol. 2001;19:398-405.

140. Grange F, Joly P, Barbe C, Bagot M, Dalle S, Ingen-Housz-Oro S, et al. Improvement of Survival in Patients With Primary Cutaneous Diffuse Large B-Cell Lymphoma, Leg Type, in France. JAMA Dermatol. 2014;150:535-41.

141. Fenot M, Quereux G, Brocard A, Renaut JJ, Dreno B. Rituximab for primary cutaneous diffuse large B-cell lymphoma-leg type. Eur J Dermatol. 2010;20:753-7.

142. Guyot A, Ortonne N, Valeyrie-Allanore L, Bagot M. Combined treatment with rituximab and anthracycline-containing chemotherapy for primary cutaneous large B-cell lymphomas, leg type, in elderly patients. Arch Dermatol. 2010;146:89-91.

143. Bekkenk MW, Vermeer MH, Geerts ML, Noordijk EM, Heule F, van Voorst Vader PC, et al. Treatment of multifocal primary cutaneous B-cell lymphoma: a clinical follow-up study of 29 patients. J Clin Oncol. 1999;17:2471-8.

144. Dummer R, Kempf W, Hess Schmid M, Häffner A, Burg G. Therapy of cutaneous lymphoma--current practice and future developments. Onkologie. 2003;26:36672.

145. Dreno B. Standard and new treatments in cutaneous B-cell lymphomas. J Cutan Pathol. 2006:33:47-51.

146. Eich HT, Eich D, Micke 0, Süttzer H, Casper C, Krieg T, et al. Long-term efficacy, 
curative potential, and prognostic factors of radiotherapy in primary cutaneous B-cell lymphoma. Int J Radiat Oncol Biol Phys. 2003;55:899-906.

147. Kiyohara T, Kumakiri M, Kobayashi $\mathrm{H}$, Nakamura $\mathrm{H}$, Ohkawara A. Cutaneous marginal zone B-cell lymphoma: a case accompanied by massive plasmacytoid cells. J Am Acad Dermatol. 2003;48:S82-5.

148. Sah A, Barrans SL, Parapia LA, Jack AS, Owen RG. Cutaneous B-cell lymphoma: pathological spectrum and clinical outcome in 51 consecutive patients. Am J Hematol. 2004;75:195-9.

149. Senff NJ, Hoefnagel JJ, Neelis KJ, Vermeer MH, Noordijk EM, Willemze R, et al. Results of radiotherapy in 153 primary cutaneous B-Cell lymphomas classified according to the WHO-EORTC classification. Arch Dermatol. 2007:143:1520-6.

150. Yap LM, Blum R, Foley P, McCormack C, Turner H, Seymour JF, et al. Clinical study of primary cutaneous B-cell lymphoma using both the European Organization for Research and Treatment of Cancer and World Health Organization classifications. Australas J Dermatol. 2003;44:110-5.

151. Fernández-Guarino $\mathrm{M}$, Ortiz-Romero $\mathrm{PL}$, Fernández-Misa $\mathrm{R}$, Montalbán $\mathrm{C}$. Rituximab in the Treatment of Primary Cutaneous B-Cell Lymphoma: A Review. Actas Dermosifiliogr. 2014;105:438-45.

152. Kennedy GA, Blum R, McCormack C, Prince HM. Treatment of primary cutaneous follicular centre lymphoma with rituximab: a report of two cases. Australas Dermatol. 2004;45:34-7.

153. Fink-Puches $\mathrm{R}$, Wolf $\mathrm{IH}$, Zalaudek I, Kerl H, Cerroni L. Treatment of primary cutaneous B-cell lymphoma with rituximab. J Am Acad Dermatol. 2005;52:84753.

154. Lacouture ME, Baron JM, Jani AB, Laumann AE, Soltani K. Treatment of radiationrelapsing primary cutaneous B-cell lymphoma with an anti-CD20 monoclonal antibody. Clin Exp Dermatol. 2005;30:46-8.

155. Errante D, Bernardi D, Bianco A, De Nardi S, Salvagno L. Rituximab-related urticarial reaction in a patient treated for primary cutaneous B-cell lymphoma. Ann Oncol. 2006;17:1720-1. Ann Oncol. 2006;17:1720-1.

156. Kerl K, Prins C, Saurat JH, French LE. Intralesional and intravenous treatment of cutaneous B-cell lymphomas with the monoclonal anti-CD20 antibody rituximab: report and follow-up of eight cases. Br J Dermatol. 2006;155:1197-200.

157. Seker M, Ustaalioğlu BB, Bilici A, Yildirim ME, Kefeli U, Barisik NO, et al. Eightcycle rituximab therapy resulted in complete remission in primary cutaneous marginal zone lymphoma. Leuk Res. 2010;34:e160-3.

158. Brunet-Possenti F, Franck N, Tamburini J, Jacobelli S, Avril MF, Dupin N. Focal rituximab-induced edematous reaction at primary cutaneous follicle center lymphoma lesions: case report and literature review. Dermatology. 2011;223:2002.

159. Quéreux G, Brocard A, Peuvrel L, Nguyen JM, Knol AC, Dréno B. Systemic rituximab in multifocal primary cutaneous follicle centre lymphoma. Acta Derm Venereol. 2011;91:562-7.

160. Winkler U, Jensen M, Manzke 0, Schulz H, Diehl V, Engert A. Cytokine-release syndrome in patients with B-cell chronic lymphocytic leukemia and high lymphocyte counts after treatment with an anti-CD20 monoclonal antibody (rituximab, IDEC-C2B8). Blood. 1999;94:2217-24.

161. van der Kolk LE, Grillo-López AJ, Baars JW, Hack CE, van Oers MH. Complement activation plays a key role in the side-effects of rituximab treatment. $\mathrm{Br} \mathrm{J}$ Haematol. 2001:115:807-11.

162. Lowndes S, Darby A, Mead G, Lister A. Stevens-Johnson syndrome after treatment with rituximab. Ann Oncol. 2002;13:1948-50.

163. Hellerstedt B, Ahmed A. Delayed-type hypersensitivity reaction or serum sickness after rituximab treatment. Ann Oncol. 2003;14:1792.

164. Scheinfeld N. A review of rituximab in cutaneous medicine. Dermatol Online J. 2006;12:3.

165. Sangfelt 0, Erickson S, Castro J, Heiden T, Einhorn S, Grandér D. Induction of apoptosis and inhibition of cell growth are independent responses to interferonalpha in hematopoietic cell lines. Cell Growth Differ. 1997;8:343-52.

166. Sangfelt 0, Erickson S, Grander D. Mechanisms of interferon-induced cell cycle arrest. Front Biosci. 2000;5:D479-87.

167. Rosmaninho A, Alves R, Lima M, Lobo I, Amorim I, Selores M. Red nose: primary cutaneous marginal zone B-cell lymphoma. Leuk Res. 2010;34:682-4.

168. Kavala M, Zindanci I, Sudogan S, Can B, Turkoglu Z, Kocaturk E, et al. Primary cutaneous follicle center lymphoma responsive to interferon alfa-2a. Indian $J$ Dermatol Venereol Leprol. 2011;77:729.
169. Oliveira A, Caetano M, Alves R, Lima M, Selores M. Letter: Primary cutaneous marginal zone B-cell lymphoma of the face: a challenging diagnosis. Dermatol Online J. 2012;18:12

170. Mangana J, Zipser MC, Conrad C, Oberholzer PA, Cozzio A, Knuth A, et al. Skin problems associated with pegylated liposomal doxorubicin-more than palmoplantar erythrodysesthesia syndrome. Eur J Dermatol. 2008;18:566-70.

171. Von Moos R, Cathomas R. Skin problems associated with pegylated liposomal doxorubicin -- more than palmoplantar erythrodysesthesia syndrome. Eur $J$ Dermatol. 2009;19:264-5.

172. Degen A, Alter M, Schenck F, Satzger I, Völker B, Kapp A, et al. The handfoot-syndrome associated with medical tumor therapy - classification and management. J Dtsch Dermatol Ges. 2010;8:652-61.
MAILING ADDRESS:

Margarida Lima

Laboratório de Citometria, Serviço de Hematologia e Consulta Multidisciplinar de Linfomas Cutâneos

Hospital de Santo António, Centro Hospitalar do Porto

D. Manuel II St.,

4099-001 Porto

Portugal

Emails: mmc.lima@clix.pt; margaridalima@chporto.minsaude.pt

How to cite this article: Lima M. Cutaneous primary B-cell lymphomas: from diagnosis to treatment. An Bras Dermatol. 2015;90(5):687-706. 